Universidad de Lima

Escuela de Posgrado

Maestría en Tributación y Política Fiscal

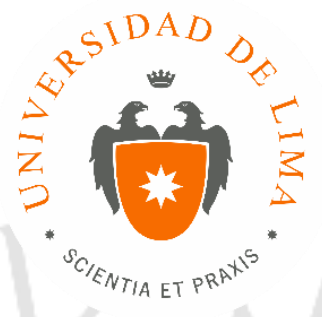

\title{
LA CARGA DE LA PRUEBA EN EL PROCEDIMIENTO DE FISCALIZACIÓN: NECESIDAD DE SU REGULACIÓN
}

Trabajo de investigación para optar el Grado Académico de Maestro en

Tributación y Política Fiscal

Olinda Tunque Flores

Código 20142506

\section{Allan Dyck Reyes Morón}

Código 20142497

\section{Asesores}

Walker Villanueva Gutierrez

Lima - Perú

Julio de 2017 


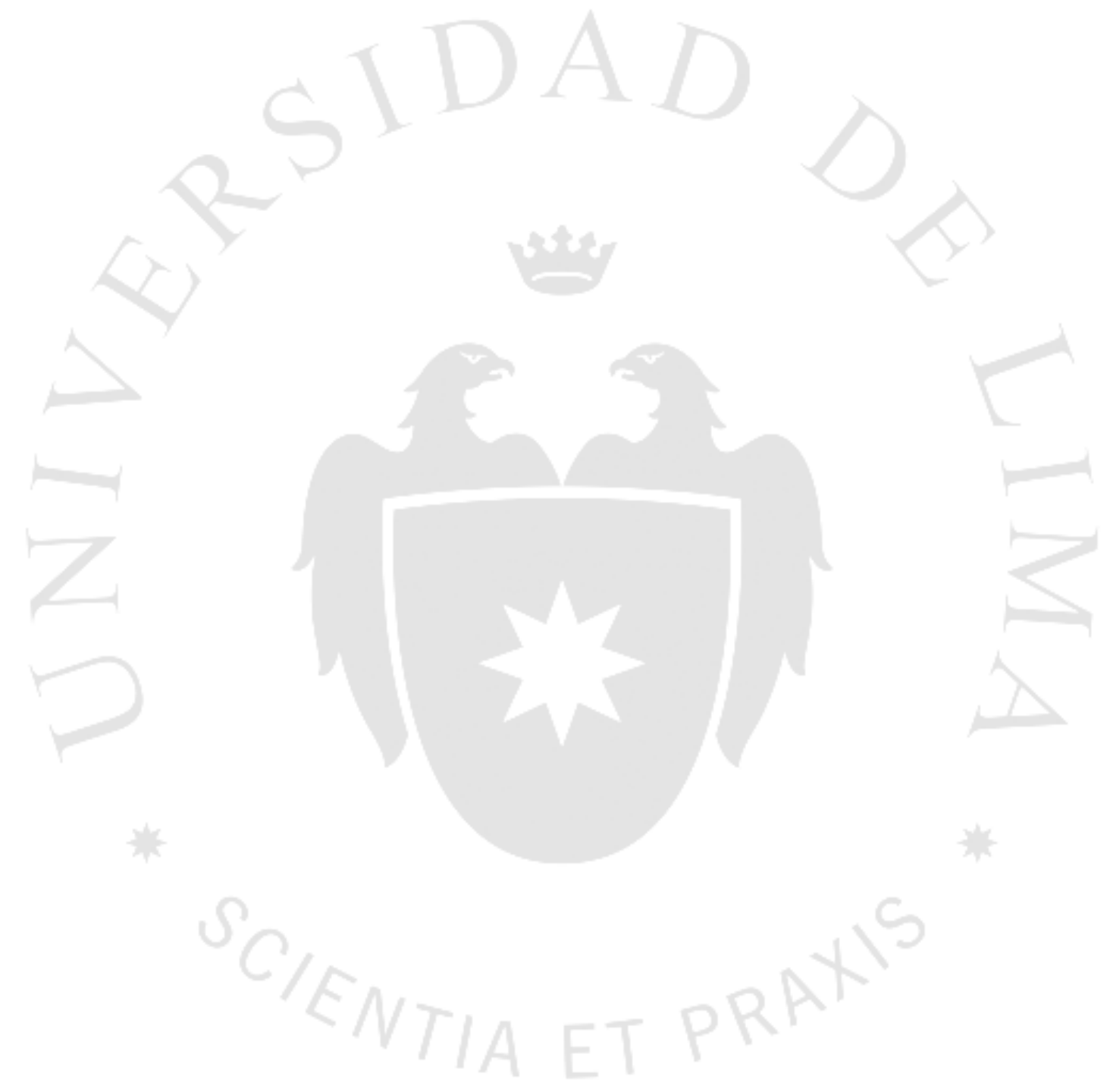




\section{LA CARGA DE LA PRUEBA EN EL PROCEDIMIENTO DE FISCALIZACIÓN: NECESIDAD DE SU REGULACIÓN}




\section{TABLA DE CONTENIDO}

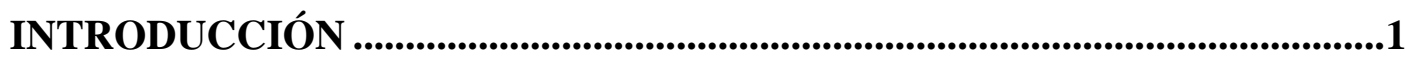

CAPÍTULO I: MARCO TEÓRICO .............................................................2

1.1 El Derecho a la Prueba......................................................................2

1.2 Definición y Objeto de la Prueba.......................................................5

1.3 La Carga de la Prueba ...................................................................

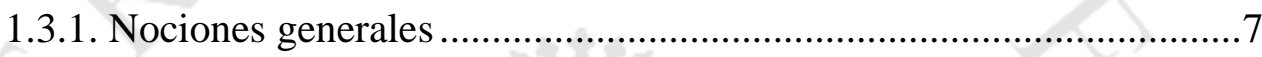

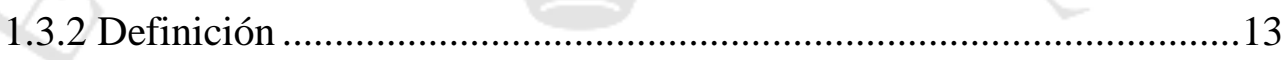

1.3.3 Funcionalidad de la carga de la prueba y su aplicación en el procedimiento de fiscalización ...........................................................15

1.3.4Teorías de la carga de la prueba ......................................................20

\section{CAPÍTULO II: PROBLEMÁTICA DE LA CARGA DE LA PRUEBA EN EL}

PROCEDIMIENTO DE FISCALIZACIÓN.......................................................40

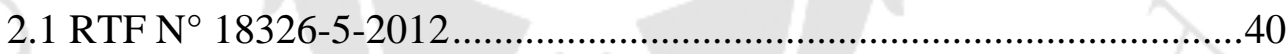

2.2 Sentencia del Expediente $\mathrm{N}^{\circ}$ 3864-2009-0......................................42

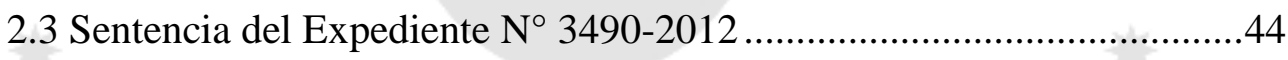

2.4 Sentencia del Expediente $\mathrm{N}^{\circ}$ 2000-2011-0......................................47

2.5 Sentencia Tribunal Constitucional Expediente Nº2647-2011-PA/TC 49

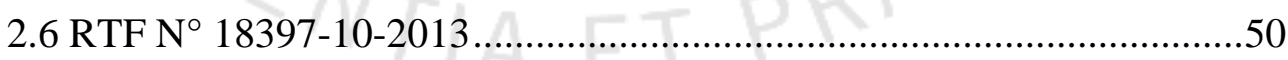

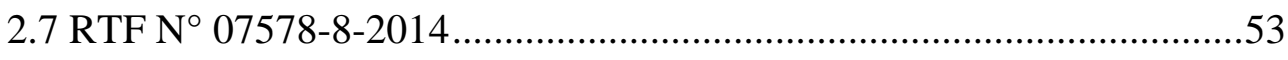

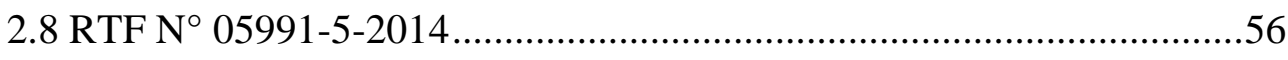

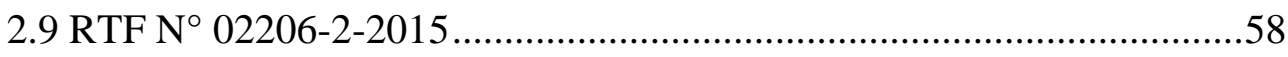

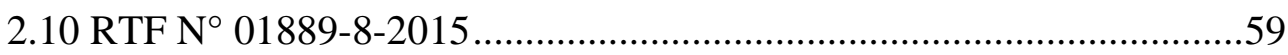

CAPÍTULO III: PROBLEMÁTICA DE LA CARGA DE LA PRUEBA EN EL

PROCEDIMIENTO FISCALIZACIÓN .................................................................62 
3.1 Problemática y necesidad de regulación de las reglas de la carga de la prueba

3.2 Postulados para establecer las reglas de la carga de la prueba en el procedimiento de fiscalización .64

3.2.1 Las reglas de la carga de la prueba se establecen de acuerdo a la materia que regulan y el tipo de procedimiento a seguir .64

3.2.2 Las reglas de la carga de la prueba se determinan dinámicamente durante el curso del procedimiento de fiscalización .65

CONCLUSIONES .78

RECOMENDACIONES .81 


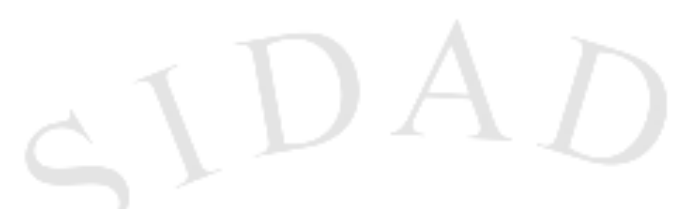

"La distribución adecuada y prudente de la carga de la prueba es una de las instituciones más necesarias o, por lo menos, más deseables del orden jurídico". Wach

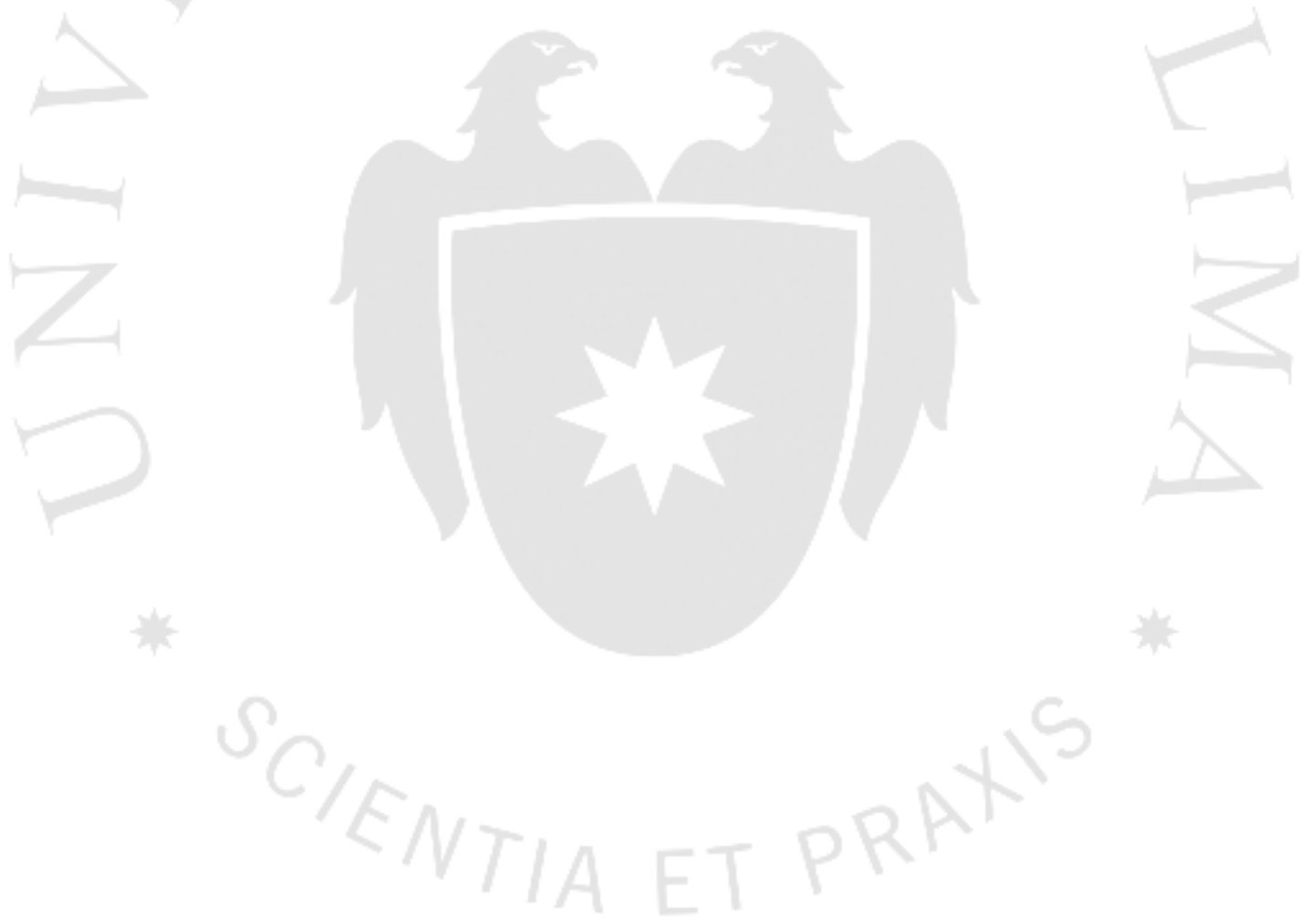




\section{INTRODUCCIÓN}

En el Derecho en general y en particular en el Derecho Tributario, quien no prueba que le corresponde un derecho, beneficio o que es titular de una situación concreta, no tendrá posibilidad de oponerlos ante terceros o ante la Administración Tributaria. De ello se colige, la importancia general de determinar a quién le corresponde la carga de la prueba dentro de un procedimiento.

Ahora bien, dicha importancia es mayor en el procedimiento de fiscalización, el cual, en virtud de su facultad de fiscalización, se inicia de oficio por la Administración Tributaria a fin de verificar el cumplimiento de las obligaciones tributarias de los contribuyentes, quienes están obligados a presentar la información requerida por ésta.

En efecto, el resultado de dicho procedimiento puede dar lugar a la determinación de omisiones en el pago de obligaciones tributarias, que incidirán en la esfera patrimonial de los contribuyentes, por lo que siendo el procedimiento de fiscalización la instancia en la cual la Administración Tributaria determina la obligación tributaria, resulta necesario tener certeza de cuáles son las reglas de la carga de la prueba dentro del mismo, a fin de que tanto la Administración Tributaria como los contribuyentes conozcan de forma previa a quién le corresponde la carga de la prueba y qué se debe probar.

Por tal motivo, en el presente trabajo de investigación abordaremos la problemática entorno a la carga de la prueba dentro del procedimiento de fiscalización, específicamente, definiremos ¿Cuáles son las teorías de las reglas de la carga de la prueba en el procedimiento de fiscalización? ¿Están reguladas dichas teorías en el ordenamiento jurídico peruano? Asimismo, revisaremos casos resueltos por el Tribunal Fiscal, el Poder Judicial y el Tribunal Constitucional a fin de determinar ¿Cuáles son las teorías de la carga de la prueba que aplicaron dichos órganos? ¿Es necesaria la regulación de las reglas de la carga de la prueba en dicho procedimiento? y ¿Cuáles son las reglas de la carga de la prueba que correspondía aplicar en los mismos?. Dicho esto, a continuación empezaremos con el desarrollo de nuestro tema de investigación. 


\section{CAPÍTULO I: MARCO TEÓRICO}

El presente trabajo de investigación desarrollará la problemática de la carga de la prueba en el procedimiento de fiscalización, a fin de determinar si resulta necesario establecer y regular las reglas generales respecto de la carga de la prueba en dicho procedimiento. Para tal efecto, comenzaremos con la exposición de los conceptos generales sobre la institución de la prueba, carga de la prueba, el procedimiento administrativo de fiscalización y las teorías respecto a las reglas de la carga de la prueba.

\subsection{El Derecho a la Prueba}

Para entender plenamente los alcances de la prueba, resulta necesario partir de lo establecido al respecto en nuestra carta fundamental, esto es, de la Constitución Política del Perú de 1993, para posteriormente, en los acápites siguientes del presente trabajo de investigación, analizar el desarrollo de dicha institución en las leyes especiales y en particular en el Código Tributario, toda vez que, como el profesor Morales afirma:

Las Constituciones ejercen un efecto de irradiación o fuerza expansiva, en el sentido que todas las demás normas constitucionales, las leyes ordinarias, así como las demás normas de inferior jerarquía deben tenerlas como parámetros, tanto por parte de los legisladores como por los operadores de derecho. (Priori et al., 2013, p. 263)

En ese sentido, de acuerdo a lo establecido en el tercer inciso del artículo $139^{\circ}$ de la Constitución es principio y derecho de la función jurisdiccional, la observancia del debido proceso y la tutela jurisdiccional; siendo que el Tribunal Constitucional en las sentencias recaídas en los Expedientes $\mathrm{N}^{\circ}$ 1034-96-AA/TC, 43-96-AA/TC y 3-2004$\mathrm{AI} / \mathrm{TC}$ ha establecido que dicho principio y derecho se aplica también al procedimiento administrativo.

Ahora, si bien la citada norma no regula expresamente a la prueba como derecho fundamental, de acuerdo a la Sentencia $N^{\circ}$ 010-2002-AI/TC, dicho Tribunal ha señalado "que el derecho fundamental a la prueba tiene protección constitucional, en la medida en que se trata de un derecho comprendido en el contenido esencial del derecho 
al debido proceso, reconocido en el inciso 3 del artículo $139^{\circ}$ de la Constitución"; agrega que "una de las garantías que asisten a las partes del proceso es la de presentar los medios probatorios necesarios que posibiliten la creación de convicción en el juzgador sobre la veracidad de sus argumentos”. (como se citó en Eto, 2011, p. 216)

La citada sentencia precisa que:

El derecho a la prueba lleva aparejada la posibilidad de postular, dentro de los límites y alcances que la Constitución y las leyes reconocen, los medios probatorios pertinentes para justificar los argumentos que el justiciable esgrime a su favor. Por ello, no se puede negar la existencia del derecho fundamental a la prueba. Constituye un derecho fundamental de los justiciables producir la prueba relacionada con los hechos que configuran su pretensión o su defensa. (como se citó en Eto, 2011, p. 216)

En la Sentencia $\mathrm{N}^{\circ}$ 6712-2005-PHC/TC, el Tribunal Constitucional entiende respecto al derecho constitucional a probar:

Se trata de un derecho complejo que está compuesto por el derecho a ofrecer medios probatorios que se consideren necesarios, a que éstos sean admitidos, adecuadamente actuados, que se asegure la producción o conservación de la prueba a partir de la actuación anticipada de medios probatorios y que éstos sean valorados de manera adecuada y con la motivación debida, con el fin de darle el mérito probatorio que tenga en la sentencia. La valoración de la prueba debe estar debidamente motivada por escrito, con la finalidad de que el justiciable pueda comprobar si dicho mérito ha sido efectiva y adecuadamente realizado. (como se citó en Eto, 2011, p. 217)

Por su parte, el profesor Morales delimita el contenido esencial del derecho a la prueba en los siguientes componentes importantes:

\section{a) Derecho a ofrecer medios probatorios.-}

Es el primer contenido esencial del derecho a la prueba. En efecto, las partes que intervienen en un proceso y los terceros legitimados, tienen el derecho de ofrecer los medios probatorios que consideren pertinentes para acreditar los hechos que constituyen sus hipótesis (...).

\section{b) Derecho a la admisión de medios probatorios.-}

Si bien el derecho a la prueba es considerado como un derecho fundamental, y las partes deben tener la oportunidad de ofrecer los medios probatorios que 
consideren pertinentes, este derecho no es absoluto, tiene limitaciones, en función a los principios procesales que rigen el tema probatorio (...). En otras palabras, el juez no debe admitir necesariamente todos los medios probatorios ofrecidos por las partes, porque éstos estarán limitados por los principios de preclusión, pertinencia, licitud, etc. (...).

Sin embargo, precisa el referido autor, citando a Picó Y Junoy, Joan, que la no admisión de un medio probatorio debe estar debidamente fundamentada, porque de lo contrario sería un acto arbitrario por parte del juzgador, y podría estar colocando a la parte afectada en situación de indefensión.

\section{c) Derecho a que se actúen los medios probatorios.-}

Una vez que se admitan los medios probatorios por el Juez, éstos deben ser actuados en audiencia de pruebas (...). La omisión o defecto en la actuación de algún medio probatorio admitido, puede determinar la nulidad de la sentencia, porque, habría colocado a la parte afectada en situación de indefensión (...).

\section{d) Derecho a que sean debidamente valorados los medios probatorios.-}

Este es el momento cúspide del derecho a la prueba. El juez, de acuerdo al sistema de valoración de la prueba que adopta nuestro sistema jurídico procesal, debe apreciar los medios probatorios desarrollados en el proceso de manera crítica; su apreciación debe ser razonada, para poder justificar su decisión. (Priori et al., 2013, pp. 264 - 269)

De lo expuesto, podemos afirmar que el derecho a la prueba constituye un derecho fundamental que forma parte del derecho al debido proceso, cuyo contenido esencial comprende el derecho a ofrecer medios probatorios y a que éstos sean debidamente valorados. Sin embargo, dicho derecho no es absoluto, encontrándose limitado por las disposiciones constitucionales así como por aquellas establecidas en leyes ordinarias.

Ahora bien, conviene precisar que nuestro tema de análisis específico es la carga de la prueba dentro del procedimiento de fiscalización, es decir, a quién le corresponde probar en dicho procedimiento y sobre qué aspecto, sin perjuicio de la vigencia del 
derecho fundamental a probar que tienen los administrados/contribuyentes dentro del mismo.

\subsection{Definición y Objeto de la Prueba}

Como señala, Del Padre (2012) "El término prueba, así como tantos otros, encuentra en el uso ordinario y jurídico los más diversos significados. Este vocablo deriva del latín probatio, que significa ensayo, verificación, inspección, examen, argumento, razón, aprobación, confirmación". (p. 105)

Evidentemente, la acepción que aquí nos interesa, es la del ámbito jurídico, “lo cual exige como paso ineludible, el estudio de la institución en su dimensión o vertiente procesal. Por el hecho incuestionable de que ha sido en el ámbito del Derecho Procesal donde este concepto se ha elaborado" (Barrero, 2006, p. 41). Así también lo manifiestan los profesores españoles Garcia de Enterría y Tomás-Ramón (2006), al señalar que "se hace necesario acudir a los principios generales del procedimiento como institución jurídica, principios que aparecen positivados únicamente en la regulación del procedimiento más desarrollado que, es naturalmente, el judicial" (p. 1434).

La prueba, puede ser definida como "aquel conjunto de operaciones que tratan de obtener la convicción psicológica del juzgador respecto de un dato procesal determinado". (como se citó en Barrero, 2006, p. 216)

En esa línea de criterio, Hernández (2006), define la prueba como: "La actividad de las partes dentro de un proceso judicial o procedimiento administrativo dirigida a convencer al juez o al administrador de la veracidad de unos determinados hechos que se afirman existentes en la realidad”. (p. 281)

El Objeto de la prueba es la demostración de aquellos hechos fácticos que han de servir de fundamento a la resolución judicial, lo que debe probarse son los hechos ${ }^{1}$, no el Derecho. "La prueba desarrollada en el proceso civil, presupone la existencia de

\footnotetext{
${ }^{1}$ Pero no todos los hechos deben probarse:

a) Los hechos "pacíficos" no requieren prueba: o sea, los hechos no controvertidos, los que las partes aceptan sin contradicción. En virtud de la admisión de tales hechos por las partes, el juez debe tenerlos por acreditados (así por ejemplo, si el demandante invoca un contrato de compraventa como fuente de su crédito, y el demandado reconoce dicho contrato, pero afirma que pagó el saldo del precio).

b) Los hechos "notorios" tampoco necesitan ser probados. Son hechos notorios aquellos cuya existencia es conocida por la generalidad de los individuos de cultura media, en el tiempo y en el lugar que se dicta la sentencia.
} 
hechos discutidos; de hechos sustentados por una de las partes y no aceptados por la otra”. (Barrero, 2006, pp. 44-46).

En el ámbito procesal, tenemos que para Hernández (2006), que analiza su definición en los procesos constitucionales, es:

El hecho o los hechos de cuya existencia o inexistencia ha de convencerse el juez constitucional. Es por tanto, una actividad complementaria de las violaciones constitucionales alegadas.

La actividad probatoria, en principio, sólo tiene por objeto los hechos, no las normas jurídicas, dado que el juez conoce el derecho. Por tanto, salvo el caso de que se trate de acreditar costumbres, la prueba únicamente puede versar sobre los hechos de los que dependa la estimación o desestimación de la pretensión, siempre y cuando sean dudosos o controvertidos. (p. 286)

Por su parte, López (2012), analizando qué se prueba en los procesos constitucionales, señala que:

La actividad probatoria solo tiene por objeto los hechos, dado que el juez constitucional conoce el derecho, por lo tanto, la prueba únicamente puede versar sobre los hechos de los que dependa la estimatoria o desestimatoria de la demanda constitucional, es decir, sobre los hechos relacionados con la vulneración o no del derecho constitucional, con la existencia del acto lesivo reclamado y, en algunos casos, con la titularidad del derecho constitucional vulnerado (derecho a la propiedad sobre un determinado bien, el derecho a la pensión, el derecho a no ser despedido sino por causa justa, etc.). (pp. 56-59)

La profesora Ariano (2013) anota que "El thema probandum, en cambio, está constituido por el conjunto de hechos alegados por las partes sobre los que debe girar en concreto la actividad probatoria, en cuanto sobre ellos resulta necesaria su confirmación". (Priori et al., 2013, p. 263).

En tal sentido, podemos afirmar que el objeto de la prueba dentro de un proceso judicial consiste en el hecho o hechos que sustentan las afirmaciones o pretensiones de las partes dentro de un proceso.

Ahora bien, en el campo administrativo por lo general no se discute la verificación de hechos alegados por dos o más partes, sino que es el administrado quien se presenta ante la Administración Pública en busca de la declaración de un derecho o ésta la que inicia un procedimiento de oficio; siendo el objeto de la prueba distinto en 
uno u otro caso, preliminarmente indicamos que en el primer caso, el objeto de la prueba lo constituirá, el hecho o hechos que sustentan el derecho del administrado; mientras que en el segundo, aquellos que sustentan las afirmaciones del administrado, así como resolución de la Administración Pública; más adelante en el desarrollo de la normativa administrativa detallaremos este tema.

\subsection{La Carga de la Prueba}

\subsubsection{Nociones generales}

\subsubsection{Antecedentes}

Cabe precisar que la carga de la prueba se encuentra íntimamente vinculada al concepto de prueba que hemos mencionado anteriormente, por ello revisaremos lo expuesto por Echeandía (2012) en relación a la evolución del concepto de prueba judicial en el Derecho Clásico y Moderno, quien, a su vez, se sustenta en el autor italiano Alessandro Giuliani para precisar lo siguiente:

El movimiento jurídico originado en el resurgimiento del derecho romano trajo como era natural, un concepto clásico de la prueba, cuyas características esenciales son: a) se considera a la prueba como un argumentum, es decir, como algo retórico y abstracto; b) la actividad probatoria está dominada por la lógica, la ética (...); c) el sistema probatorio se basa en el principio de la carga de la prueba y en la identificación de lo probable con lo éticamente preferible y se limita el campo de la investigación a lo más importante o relevante, en virtud de la llamada teoría de las exclusiones. De este concepto clásico de la prueba, nace la teoría de las presunciones como un razonamiento o juicio y se le otorga demasiada importancia a las pruebas judiciales, hasta el punto de identificarlas con la ciencia jurídica y de no concebir el derecho subjetivo sin su prueba.

Tal es el panorama conceptual en materia de pruebas durante la Edad Media.

A partir del siglo XIII comienza la decadencia de la tradición retórica y aparece el concepto de lo probable sobre bases objetivas, es decir, de acuerdo con lo que comúnmente ocurre en la realidad, en ese sentido, se considera la reconstrucción del hecho como objeto de la investigación. Además, se regula el grado de probabilidad que 
se debe reconocer a los distintos medios de prueba y se separa, por ese aspecto, la prueba y la investigación judicial de la realidad de los casos concretos.

En el siglo XIV aparece el principio de la investigación oficiosa del derecho por el juez (...). El razonamiento jurídico se concibe como un silogismo en su más estricto sentido y el fundamento de la teoría de las presunciones se busca con un criterio objetivo de probabilidad. Por otra parte, el iusnaturalismo trata de superar los límites de la teoría de la verdad probable, utilizando los principios de lo que se llamó la aritmética de la prueba, y así la validez del testimonio se basa en el criterio numérico o cuantitativo, otorgándose un valor exagerado a la prueba testimonial.

Del siglo XVI en adelante se le da una mayor intervención tanto al Estado, con el desarrollo de la prueba documental por medio de los funcionarios que intervienen en esta, como al juez, mediante poderes investigativos (...). Se elabora el concepto de la prueba legal en base a las reglas de la experiencia de siglos anteriores y se sustituye el criterio subjetivo de los jueces.

Según opina Giuliani: Bentham introduce en el derecho el concepto moderno de prueba, basado en el método inductivo y las máximas de la experiencia que con él se elaboran, siendo la esencia del concepto de la prueba consiste desde entonces en pasar de un hecho conocido a un hecho desconocido, es decir, se identifica el razonamiento jurídico con el silogismo. Además, Bentham creía en un método objetivo y cuantitativo para valorarla $^{2}$, elaborado sobre un previo cálculo de probabilidades. Esto es, adopta y defiende el sistema de la tarifa legal estricta.

De este modo, en el derecho moderno el concepto de prueba se basa en la lógica inductiva y en la experiencia y la investigación de los hechos aparece como una cuestión técnica, se exageró la importancia de la lógica inductiva, hasta llegar a identificar la prueba judicial con la prueba indirecta, negándole el carácter de tal a la directa.

El movimiento de liberación y revaluación de la persona humana frente al Estado, que condujo a la Revolución Francesa y que se expandió gracias a esta por toda Europa, rechazó el sistema de tarifa legal y la concepción del razonamiento judicial como un puro silogismo, por tanto, se implantó la libertad de apreciación de las pruebas por el juez, primero en el derecho penal y luego en lo civil. De esta manera, se amplió el campo de investigación del juez, que debe recurrir ya no solo a la lógica sino a la psicología, a la técnica y a las nuevas ciencias empíricas, para la valoración de la prueba.

\footnotetext{
${ }^{2}$ Haciendo referencia a la prueba.
} 
De lo mencionado previamente, surgió el panorama contemporáneo de las pruebas judiciales, esto es, la necesidad de dotar de facultades inquisitivas a los jueces en todos los procesos modernos, civil, laboral, comercial, fiscal, contencioso administrativo y, en general, en todos los procesos modernos. Esta reforma ha sido introducid también en muchos códigos del siglo XX, como los de Rusia, Alemania, Austria, Francia, Italia, Argentina, Brasil, México, Portugal, Colombia.

En tal sentido, se concibe al juez como un historiador, se elimina la exageración de identificar la prueba judicial con la indirecta y se restituye su importancia y autonomía a la prueba directa, gracias, principalmente, a Carnelutti, se reclama menos formulismos y más libertad de apreciación para el juez, en lo que viene a ser, la fase científica de las pruebas judiciales.

Así han quedado eliminadas las principales diferencias que artificialmente se habían creado entre la prueba penal y civil, y se ha despejado el camino para una teoría general de la prueba judicial, con sus principios rectores comunes. (pp. 58-63).

Por su parte, específicamente sobre la historia de la carga de la prueba, Montero (2011) anota lo siguiente:

En las máximas romanas o medievales, los posglosadores, intentaron generalizar la regla respecto a que si el demandado se limita a negar los hechos afirmados por el actor no soporta carga probatoria alguna. Posteriormente, la carga probatoria se sustentó en la clase de hechos a probar, atribuyendo al actor la carga de probar los hechos constitutivos y al demandado los hechos extintivos, todavía se dio un paso adelante cuando se distinguió la carga probatoria en base a las condiciones generales y específicas de la existencia de las relaciones jurídicas, debiendo probar el demandante las segundas y el demandado las primeras, conforme indicó Chiovenda. Finalmente, Rosenberg sostuvo que cada parte debe afirmar y probar los presupuestos de la norma que le es favorable. (pp.124-129).

En esa misma línea, precisa Falcón que (2009):

En todas las etapas históricas, representó -como hemos dicho- un verdadero avance la distinción entre hechos constitutivos, impeditivos y extintivos, que tuvo su origen en el art. 1315 del Código de Napoleón: El que reclama la ejecución de una obligación, debe probarla. Recíprocamente, el que pretende estar libre, debe justificar el pago o el hecho que ha producido la extinción de su obligación.

La carga de la prueba no es exclusiva del derecho continental. En el common law, específicamente en los Estados Unidos de América, ha habido estudios sobre el tema 
desde antaño. En 1886, Bailey publicó una obra sobre el "onus probandi", hizo un análisis temático y casuístico sobre la aplicación de estas reglas, basado en la jurisprudencia; siendo que "en la actualidad, la expresión "onus probandi" ha desaparecido prácticamente del derecho estadounidense, que la entiende como carga de la prueba en sentido estricto, una situación en la cual, si la prueba aducida por la parte que tiene la carga no es realizada, el resultado será contra el que tiene la carga (pp.276278).

Como se aprecia, los antecedentes de la carga de la prueba los podemos encontrar en el Derecho Procesal, en el cual se establecieron paulatinamente distintas reglas sobre la misma, las cuales fueron recogidas por los ordenamientos jurídicos de distintos países.

\subsubsection{Distinción entre carga procesal, deber y obligación}

Iniciado el proceso civil en virtud de impulso original nacido en el conflicto (que dio lugar al interés en el proceso), surgen para las partes, correlativamente los deberes y obligaciones, como imperativos jurídicos al lado de la cargas del proceso. (Donaires, 2014, p. 2).

Al respecto, Falcón (2009) señala lo siguiente:

Lo primero que corresponde señalar es la diferencia entre deber, obligación y carga, en el marco del proceso en general y de la prueba en particular, para poder con ese deslinde con ese deslinde de conceptos, fijar -aunque sea de modo preliminar- la idea de carga (...)."Los deberes son para los sujetos públicos, aquellos citados al proceso, y en algunos casos para las partes (como el deber ético); en cambio, las cargas son siempre para las partes".

Las palabras "deber y obligación" se confunden y a veces se usan como sinónimo, ligado en muchos aspectos con la oposición derecho-deber y -entre otros- con la norma autónoma moral y la heterónoma jurídica (...). Sin embargo, desde el punto de vista estricto (...), se puede diferenciar claramente la obligación del deber. Según una reciente determinación, los deberes deben distinguirse entre los que no sean correlativos a otros derechos subjetivos (deberes en sentido propio), o que sean correlativos a otros derechos subjetivos; a estos últimos se les debería reservar el término de obligaciones (obblighi).

El deber aparece cuando el derecho en el cual se sustenta el cumplimiento de determinada conducta se funda en un vínculo originado en el ámbito social, no para 
preservar el patrimonio que pueda tener una persona de modo individual (existe o no este campo patrimonial), sino la conducta hacia la sociedad en conjunto; mientras que la obligación es el vínculo al cual se encuentra sometido una persona (deudor) respecto de otra (acreedor), por razón de una prestación, en caso de no hacerlo será alcanzado por la sanción. (p. 267-270).

En el mismo sentido, Escribano, Blume, Gamba, Bravo y Yacolca (2010) señalan que "por deber jurídico se entiende a la necesidad de ajustar la conducta a los mandatos que emanan de una norma legal" (p.118).

Sobre al particular, Montero (2011) precisa:

La noción de carga, como contrapuesta a la de obligación, se debe fundamentalmente a Goldschimdt y Carnelutti. Para la comprensión del primero hay que partir de su teoría del proceso como situación jurídica, conforme a la cual los nexos existentes entre las partes no son principalmente derechos y obligaciones, sino expectativas, posibilidades, cargas y liberación de cargas; en este contexto la carga es "la necesidad de realizar un acto para prevenir un perjuicio procesal", de modo que se tiene la carga de comparecer, de contestar a la demanda, de probar, etc.

Por su parte, Carnelutti, que empezó diciendo que la distinción entre carga y obligación se fundaba en:

La diversa sanción conminada a quien no realiza el acto; existe sólo obligación cuando la inercia da lugar a una sanción jurídica (ejecución o pena); en cambio, si la abstención del acto hace perder los efectos útiles del mismo, tenemos la figura de la carga. (p. 116117).

Sobre la posición de Goldschimdt en relación a la carga procesal, Falcón (2009) agrega: La carga procesal es el peso jurídico al que se ven sometidas las partes del proceso si quieren obtener el resultado que el sistema le otorga a quienes realizan los actos en la forma y tiempo que dispone ese sistema. (p.271).

En el mismo sentido, Michelli (1989) señala lo siguiente:

La noción sobre la cual se ha hecho girar toda la teoría de la carga de la prueba, es precisamente la de carga entendida como entidad jurídica distinta de la obligación, en el sentido que en determinados casos la norma jurídica fija la conducta que es necesario observar, cuando un sujeto quiera conseguir un resultado jurídicamente relevante, siendo que la no observancia de esta última, pues, no conduce a una sanción jurídica, sino precisamente a la no obtención de aquel fin, conducirá por tanto, a una situación de 
desventaja para el sujeto titular del interés tutelado. Por su parte, la obligación está caracterizada por el vínculo impuesto a la voluntad del obligado por un interés ajeno; vínculo cuya violación importa ilicitud, en cuanto es violación de un mandato que no deja al obligado libertad de elección. (p. 54-55).

Anota Hurtado Reyes (2009) que la carga procesal:

Está basada fundamentalmente en la "autonomía privada", el sujeto no tiene la obligación de realizar determinados actos procesales, sino que más bien la realización de los mismos dependen de la decisión personal que tome de ejecutarlos, es decir, que el sujeto ostenta la facultad de realizarlo, queda dentro de su dominio, siendo que la inactividad procesal puede generar resultados adversos en el proceso para aquel que no produjo determinado acto procesal, inclusive este resultado puede abarcar el resultado final del proceso. De esta manera, constituyen cargas procesales la interposición de la demanda, la contestación de la misma, el impulso del proceso, la impugnación, la ejecución de las sentencias así como la carga probatoria (p.568-569).

Echeandía (2012) anota que:

Las diferencias entre la carga y la obligación o el deber pueden resumirse así:

a) La obligación y el deber son relaciones jurídicas pasivas, y la carga de la prueba es una relación jurídica activa;

b) En la obligación y el deber existe un vínculo jurídico entre el sujeto pasivo y otra persona o el Estado, el cual no existe en la carga;

c) En la obligación o el deber se limita la libertad del sujeto pasivo, mientras que en la carga conserva completa la libertad de ordenar su conducta;

d) En la obligación o deber existe un derecho (privado o público) de otra persona a exigir su cumplimiento, cosa que no sucede con la carga;

e) La obligación o el deber implican, por consiguiente, una sujeción, y la carga, por el contrario, contiene una facultad o poder.

f) El incumplimiento de la obligación o el deber es un ilícito que ocasiona sanción, mientras que la inobservancia de la carga es lícita, y por tanto, no es sancionable;

g) Existen obligaciones y deberes de no hacer y las cargas se refieren siempre a la ejecución de actos o conductas positivas.

h) El cumplimiento de la obligación o el deber beneficia siempre a otra persona o a la colectividad, al paso que la observación de la carga solo beneficia al sujeto de ella; por esto no puede decirse que aquellos satisfacen un interés ajeno y ésta solo un 
interés propio (sin que deje de existir en el primer caso un interés propio en liberarse de la obligación o el deber, esto es, en adquirir libertad). (p.401).

De acuerdo a lo expuesto, podemos concluir que el deber, la obligación y la carga procesal son instituciones jurídicas distintas, toda vez que en el deber y obligación el sujeto se encuentra constreñido a cumplir con un acto en interés ajeno (público o privado) y, en caso de incumplimiento, será objeto de sanción; mientras que el sujeto que tiene una carga procesal se encuentra facultado a cumplirla en beneficio o interés propio, siendo que su incumplimiento le ocasionará una desventaja dentro del proceso.

\subsubsection{Definición}

La carga de la prueba es una especie o tipo de carga procesal y su desarrollo se ha dado predominantemente en el Derecho Procesal es decir, dentro del ámbito judicial, del cual se ha alimentado posteriormente el Derecho Administrativo. Comúnmente en el ámbito procesal civil por ejemplo, se entiende que quien alega un hecho debe probarlo.

"En su sentido estrictamente procesal, carga de la prueba quiere decir conducta impuesta a uno o ambos litigantes, para que acrediten la verdad de los hechos enunciados por ellos", "un imperativo del propio interés" (Couture ,1973, p.241-242); siendo "paralela a la carga de la afirmación” (Carnelutti, 1952, p.98).

Santis (1979), citando a Carnelutti señala

El juez debe recurrir a las reglas sobre la carga de la prueba sólo cuando con los medios a su disposición no pueda conocer la realidad de los hechos sobre los que tiene que decidir; el mecanismo de la carga de la prueba es un expediente que se le ofrece para fijar en su sentencia los hechos desconocidos, es decir, los hechos no comprobables por los medios y con las fuentes de prueba. (como se cito en Santis, p.127).

La carga de la prueba realiza dos funciones: la una consistente en dar al juez un criterio, a base del cual decidir en todo caso, a fin de evitar un nom liquet; la otra que se concreta en el estímulo a la actividad procesal de las partes. (como se cito en Michelli,1989, p.100).

Por su parte, Echeandía (2012), afirma:

La carga de la prueba es una noción procesal que contiene la regla de juicio por medio de la cual se le indica al juez cómo debe fallar cuando no encuentre en el proceso pruebas que le den certeza sobre los hechos que deben fundamentar su decisión, e 
indirectamente establece a cuál de las partes le interesa la prueba de tales hechos, para evitarse consecuencias desfavorables. (p.406).

En el mismo sentido, Campos, 2012-2013, agrega sobre la carga de la prueba:

De un lado le indica al juez como debe sentenciar cuando no aparezcan en el proceso las pruebas que le den certeza sobre los hechos que deben sustentar su decisión y, de otro lado, a las partes la responsabilidad que tienen para que los hechos que sirven de sustento de sus posiciones aparezcan demostrados. (p. 203)

Como se aprecia la doctrina le otorga a la carga de la prueba dos funciones, las cuales permiten distinguir entre carga de la prueba subjetiva y carga de la prueba objetivo, como a continuación explicaremos:

\subsubsection{Carga de la prueba subjetiva}

Es aquella vinculada a la carga de suministrar la prueba, la cual según la definición muy difundida, "consiste en la necesidad práctica de probar una relación o un hecho reales para evitar una decisión favorable" (Rosenberg, 1956, p.17).

En tal sentido, la carga formal o subjetiva de la prueba "establece las reglas de distribución de los hechos a probar entre las partes” (Rodríguez-Bereijo, 2012, p.15).

\subsubsection{Carga de la prueba objetiva}

Es aquella que determina las consecuencias de la incertidumbre acerca de un hecho (Rosenberg, 1956, p.21), la cual también es denominada carga material y "corresponde a la regla de juicio que el ordenamiento impone al juez para solucionar los supuestos de hecho inciertos". (Rodríguez-Bereijo, 2012, p.15).

Como se aprecia la carga de la prueba puede ser vista desde dos perspectivas, aquella referida a quién le corresponde aportar las pruebas para dilucidar el hecho controvertido (carga de la prueba subjetiva o formal) y la regla de juicio que establece quién soportará las consecuencias de la falta de prueba sobre el mismo (carga de la prueba objetiva o material). Al respecto, coincidimos con Barrero (2006) al señalar que "la carga subjetiva y objetiva de la prueba se complementan de manera inescindible, toda vez que, en principio, para determinar la parte procesal que resultará perjudicada 
ante la falta de prueba debe establecerse quien le correspondía presentar dicha prueba" (p.184).

\subsubsection{Funcionalidad de la carga de la prueba y su aplicación en el procedimiento de fiscalización}

\subsubsection{El procedimiento de fiscalización}

Antes de explicar en qué consiste el procedimiento de fiscalización, conviene anotar que en nuestro ordenamiento jurídico, el Texto Único Ordenado de la Ley del Procedimiento Administrativo General - Ley $\mathrm{N}^{\mathrm{o}} 27444^{3}$, aprobado por Decreto Supremo $\mathrm{N}^{\circ}$ 006-2017-JUS (LPAG) es aquella que resulta aplicable a todas las entidades de la Administración Pública y regula las actuaciones de la función administrativa del Estado y el procedimiento administrativo común desarrollado en las entidades, tal como lo disponen sus artículo I y II del Título Preliminar de la LPAG.

En tal sentido, el artículo $44^{\circ}$ de la mencionada ley establece que el procedimiento administrativo es el conjunto de actos y diligencias tramitados en las entidades, conducentes a la emisión de un acto administrativo que produzca efectos jurídicos individuales o individualizables sobre intereses, obligaciones o derechos de los administrados.

Agrega el citado artículo II que los procedimientos especiales creados y regulados como tales por ley expresa, atendiendo a la singularidad de la materia, se rigen supletoriamente por la presente ley en aquellos aspectos no previstos y en los que no son tratados expresamente de modo distinto; por lo que las autoridades administrativas al reglamentar dichos procedimientos especiales, cumplirán con seguir los principios administrativos así como los derechos y los deberes de los sujetos del procedimiento establecidos en dicha ley.

Analizando lo dispuesto por la LPAG, Escribano et al. (2010) indican lo siguiente:

\footnotetext{
${ }^{3}$ La codificación del Derecho Administrativo, a través de leyes reguladoras del procedimiento administrativo, puede considerarse como una de las características más destacadas del derecho público hispanoamericano. El proceso se inició en España (1957-1958) y ha seguido en América Latina, en Argentina (1972), Uruguay (1973), Costa Rica (1978), Venezuela (1981), Colombia (1984), Honduras (1987), México (1994), Brasil (1999) y Perú (2001). (Brewer-Carías, 2003).
} 
El procedimiento administrativo constituye una garantía esencial de los administrados, toda vez que implica la vía previa que necesariamente debe seguir la Administración para la emisión de un acto administrativo legítimo, siendo que mediante dicho procedimiento cumple el fin de servir al interés público, así como se garantiza que los actos administrativos se sometan plenamente al ordenamiento jurídico (principio de legalidad) (p.201).

Añade Durán (2009):

En el procedimiento administrativo resulta importante la protección de los fines constitucionales que la Administración Pública debe cumplir, y es esta situación la que justifica establecer determinadas facultades de la administración y algunas limitaciones que se imponen a nivel del procedimiento llevado en esta instancia. (p.12).

Ahora bien, el procedimiento de fiscalización es una sub-especie del procedimiento administrativo, un procedimiento especial establecido a fin de que la Administración Tributaria cumpla con su labor de verificar el cumplimiento de las obligaciones tributarias. Como anota Gamba (2005) es el "conjunto de actos encaminados a verificar la veracidad de los hechos declarados por el obligado tributario, así como investigar aquellos que no fueron declarados" (p. 206).

En tal sentido, el artículo $61^{\circ}$ del Texto Único Ordenado del Código Tributario, aprobado por Decreto Supremo $\mathrm{N}^{\circ}$ 133-2013-EF, señala que la determinación de la obligación tributaria efectuada por el deudor tributario está sujeta a fiscalización o verificación por la Administración Tributaria, la que podrá modificarla cuando constate la omisión o inexactitud en la información proporcionada, emitiendo la Resolución de Determinación, Orden de Pago o Resolución de Multa. Cabe anotar que por el impulso inicial que da lugar al procedimiento, éste se clasifica como un procedimiento administrativo de oficio ${ }^{4}$.

Morón (2011) señala que el procedimiento administrativo de oficio es aquel promovido por una decisión de actuación propia de las autoridades públicas competentes, cumpliendo su deber de oficialidad inherente a su función, con el objetivo

\footnotetext{
${ }^{4}$ En opinión de Morón (2015), “el ánimo clasificatorio no puede tener sino dos fines eminentemente prácticos: la explicación didáctica de la disciplina y de la determinación de las reglas jurídicas aplicables a cada una de las categorías. Por ejemplo, las entidades solo pueden cobrar de manera individualizada a los usuarios del servicio (tasa) en los procedimientos de parte y no en los de oficio, que corresponde ser financiados con los impuestos, las técnicas de los silencios administrativos y el desistimiento y abandono como forma de conclusión del procedimiento, sólo corresponden ser aplicados a los procedimientos de iniciados a instancia de parte y no a los de oficio. (p.81)
} 
de tutelar el interés público a su cargo y realizar una actividad de investigación o inspectiva, entre otras. (p.223).

De otro lado, a fin de que la Administración Tributaria cumpla con su función de fiscalización, el artículo $87^{\circ}$ del citado Código establece como obligación del contribuyente el permitir el control por la Administración Tributaria presentando las declaraciones, informes, libros de actas, registros y libros contables y demás documentos relacionados con hechos susceptibles de generar obligaciones tributarias, en la forma, plazos y condiciones que le sean requeridos.

Ahora bien, conforme se desprende de lo expuesto en acápites anteriores, y tal como señalan Garcia de Enterría y Tomás-Ramón (2006), “el problema de la prueba es una cuestión central en todo procedimiento, cualquiera sea su clase” (p. 1434). Por ello, "la determinación del sujeto que ha de aportar la prueba de los hechos, así como las consecuencias de su ausencia tiene un valor preponderante en el procedimiento administrativo". (Barrero, 2006, p. 152)

Rodriguez-Bereijo (2012), cuando habla sobre la funcionalidad de la carga de la prueba y su aplicación al ámbito fiscal, señala que:

Las reglas sobre la carga de la prueba comprenden ambos aspectos: por un lado, la determinación del umbral de certidumbre que requiere el órgano para satisfacer la pretensión y, de otro, la determinación de cuál de las partes ha de suministrar las pruebas para alcanzar dicho umbral, si no quiere sufrir una decisión adversa en el fondo del asunto. (p. 14).

De lo expuesto, podemos advertir que el procedimiento de fiscalización es aquél mediante el cual la Administración Tributaria cumple su función pública de verificar el cumplimiento de las obligaciones tributarias por parte de los contribuyentes, estando premunida de amplias facultades para ello y debiendo respetar en el mismo los derechos de los contribuyentes.

Así, en el cumplimiento de dicha función, la carga de la prueba cumple vital importancia, toda vez que determinará qué corresponde probar al contribuyente y a la Administración Tributaria, en el marco de las facultades atribuidas a ésta y de los derechos del primero.

No obstante, cabe anotar que a fin de establecer las reglas de la carga de la prueba en el procedimiento de fiscalización, debe tenerse en cuenta las características 
de la materia que el mismo regula, esto es, la obligación tributaria, que constituye una relación jurídica de carácter público, así como que dicha obligación es inicialmente determinada por el contribuyente a través de la declaración jurada tributaria que es verificada dentro del referido procedimiento, en el cual la Administración Tributaria está premunida de amplias facultades para determinar la correcta obligación tributaria, y en su caso, efectuar las observaciones que correspondan.

\subsubsection{Funcionalidad de la carga de la prueba}

La aplicación del derecho al caso concreto se produce bajo dos serios condicionamientos: "la incertidumbre reinante en torno a cómo han sucedido los hechos en el pasado y la división de las responsabilidades que el sistema jurídico impone en torno a la cuestión de a quién corresponde el trabajo de determinar cómo han sucedido los hechos". (como se citó en Rodriguez-Bereijo, 2011, p. 8)

Además, en el Derecho Tributario hay tres circunstancias que ejercen una influencia decisiva en toda la actividad probatoria ${ }^{5}$ : "los hechos, las prerrogativas de la Administración y las obligaciones formales de los contribuyentes". (Gomez, 2001, p. 5)

En tal sentido, a fin de comprender mejor la funcionalidad de la carga de la prueba en el procedimiento de fiscalización, conviene detallar los conceptos de carga de la prueba subjetiva y objetiva antes esbozados.

El concepto de carga de la prueba señala al operador jurídico dos cosas: “cuán seguro debe estar para alcanzar una decisión en un determinado ámbito jurídico (regla de juicio, grado de convicción o umbral de certidumbre y lo que debe pasar en el sistema jurídico si no se ha logrado ese determinado grado de seguridad" (RodriguezBereijo, 2012, p. 14), regla de distribución de los hechos, es decir, determinación de cuál de las partes ha de suministrar las pruebas.

Respecto a la carga de la prueba objetiva, material o regla de juico, Rosenberg (1956) anota:

\footnotetext{
${ }^{5}$ Estas circunstancias influyen y reducen el campo de actuación de la carga de la prueba estrictamente dicha en Derecho Tributario, hasta el punto de que, en principio podríamos decir que la solución a los litigios en el ámbito fiscal depende esencialmente del grado de evidencia (prueba) alcanzado en los hechos, mientras que la cuestión de saber sobre quien recaía la carga de la prueba y cómo se produce dicha atribución resulta, la más de las veces secundaria. (como se citó en Rodríguez-Bereijo, 2012, pp. 14).
} 
Tiene lugar en todo tipo de procedimiento en el cual se trata de aplicar normas jurídicas abstractas a una situación de hecho concreta, sea que en el procedimiento domina el principio de inquisición o el principio de disposición o una estructura intermediaria entre estos dos. En cambio, sólo puede hablarse de la carga subjetiva de las partes, en un procedimiento construido sobre la máxima dispositiva (...).

Agrega que la carga de la certeza o carga objetiva se manifiesta más evidentemente en los procedimientos en que rige la máxima inquisitiva porque a causa del deber de averiguar que incumbe al tribunal no se impone a las partes la carga de actividad probatoria alguna y, por otro lado, no se puede prescindir de normas relativas al caso en que no se aclare un hecho importante. (p. 21-22).

Es decir, "la carga materia u objetiva existe en todo tipo de procesos y corresponde a la regla de juicio que el ordenamiento impone al juez para solucionar los supuestos de hecho inciertos". (Rodríguez-Bereijo, 2012, p. 15).

Por su parte, la carga de la prueba subjetiva, formal o regla de distribución de la referida carga, está relacionada, justamente, a determinar a quién le corresponde probar un hecho.

En opinión de Rodriguez-Bereijo (2012), en el derecho tributario, en principio, como ámbito regido por el principio inquisitivo, no hay lugar para hablar de carga de la prueba en el sentido subjetivo ${ }^{6}$ del término, como "carga de aportación". "Este espacio lo ocupan las obligaciones de colaboración de los contribuyentes que prevén una entrega o preparación de pruebas y tienen así una funcionalidad o contenido probatorios". (p. 17).

No obstante, reiteramos nuestra posición en relación a que la carga de la prueba subjetiva y objetiva se complementan, no siendo posible que el juez o el ente administrativo apliquen la regla de juicio respecto de un hecho controvertido no demostrado (carga de la prueba objetiva) sin que previamente se haya determinado a quién le correspondía aportar la prueba sobre dicho hecho y asumir el riesgo de su falta de prueba.

\footnotetext{
${ }^{6}$ La carga subjetiva y objetiva de la prueba, formal y material, que ambos pares de conceptos se emplean. Con la carga subjetiva o formal se hace alusión a la determinación de la parte que ha de suministrar la prueba en el proceso; la carga objetiva o material, también denominada certeza, hace sin embargo, abstracción de la actividad de las partes, interesándose únicamente por las consecuencias de la falta de acreditación de los hechos. (Barrero, 2006, pp. 182-183)
} 


\subsubsection{Teorías de la carga de la prueba}

A continuación pasaremos a explicar las distintas teorías establecidas en torno a la carga de la prueba en el proceso judicial, que fueron subsumidas en el procedimiento administrativo en general y, en particular, en el procedimiento de fiscalización, así como se verificará en qué ordenamientos jurídicos han sido aplicadas dichas teorías y si han sido asumidas en nuestro país.

\subsubsection{Carga de la prueba compartida}

Históricamente la institución de la carga de la prueba ha sido informada por el principio, según el cual, "al actor le corresponde probar los hechos constitutivos que afirma y al demandado los hechos impeditivos, extintivos y/o modificativos que opone”. (Vásquez, 2010, p. 1)

Al respecto, cabe reiterar que el desarrollo respecto de a quién le corresponde probar se ha dado predominantemente en el Derecho Procesal y concretamente en el Derecho Procesal Civil, motivo por el cual esbozaremos los principales fundamentos de la carga de la prueba en dicho proceso.

Nuestro Código Procesal Civil aprobado por Decreto Legislativo $\mathrm{N}^{\circ} 768$, de fecha 4 de marzo de 1992, se encuentra regulado de acuerdo a ese principio, según se observa en el siguiente artículo:

Artículo $196^{\circ}$.- Carga de la prueba.- Salvo disposición legal diferente, la carga de probar corresponde a quien afirma hechos que configuran su pretensión, o a quien los contradice alegando nuevos hechos.

Normas similares a las precedentes han regulado históricamente el reparto probatorio en la mayoría de los sistemas normativos de corte continental (p.e., España, Brasil, Argentina, Colombia, Chile, Uruguay, Venezuela, etc.). (Vásquez, 2010, p. 1)

Sin embargo en la mayoría de ordenamientos jurídicos sea venido produciendo una flexibilización de las reglas clásicas de distribución de la carga de la prueba, bajo el influjo de la moderna doctrina de las Cargas Probatorias Dinámicas. (Vásquez, 2010, p. 1). 


\subsection{Principio dispositivo}

\section{- En el ámbito procesal}

Conviene anotar previamente, que de acuerdo al profesor español Montero (2011):

La legitimación ordinaria en el proceso civil puede efectuarse atendiendo a dos grandes supuestos:

a) Relaciones jurídicas, según las cuales, en los casos normales de Derecho Privado la tutela judicial sólo puede realizarse cuando quien comparece ante el órgano judicial afirma su titularidad del derecho subjetivo material e imputa al demandado la titularidad de la obligación.

b) Situaciones jurídicas; casos en los que la legitimación ordinaria no puede referirse a la afirmación de la titularidad de un derecho subjetivo o a la imputación de una obligación, simplemente porque no existen ni lo uno ni la otra. Cuando se trata de las materias reguladas de modo imperativo, de las situaciones jurídicas, es la ley directamente la que determina qué posición debe ocupar una persona para que pueda pedir la actuación del derecho objetivo en el caso concreto, para que esté legitimada; es lo que ocurre, por ejemplo, con la pretensión de nulidad del matrimonio y de filiación. (pp.569-570).

Como se aprecia, en el proceso civil se cuestionan intereses privados, esto es, la existencia de una relación o situación jurídica, siendo que las partes están llamadas a probar que se le reconozca un derecho o una situación jurídica concreta.

Respecto al proceso dispositivo Hurtado (2009), señala:

En éste "son las partes las que le dan inicio, proponen pretensiones y los hechos que la sustentan, incluyendo el ofrecimiento de las pruebas que corresponden a sus intereses. Son las partes las que deciden cuando impulsan el proceso y en qué momento lo pueden concluir. Estos parámetros rigen el denominado "régimen privatístico del proceso" para contraponerlo al "régimen publicístico del proceso" que sustenta el sistema inquisitivo".

"El proceso sujeto a este principio, le interesa sólo a las partes", por lo que no se puede iniciar un proceso de oficio, "ni tener en cuenta hechos ni pruebas que no han sido aportadas por las partes", "deben tener por cierto los hechos en que aquéllas estuviesen de acuerdo" y "la sentencia debe ser conforme a lo alegado y probado" (principio de congruencia procesal) (p.594).

Agrega Hinostroza (2010): 
Supone principalmente el sistema dispositivo la potestad exclusiva que tiene cada parte sobre el material probatorio que se aporta y practica en el litigio, siendo inexistente (o muy limitada) toda iniciativa del magistrado. Se aprecia que un sistema así proclama un proceso de intereses esencialmente privados. (p.111).

En relación al principio dispositivo, Del Padre (2012) anota:

La propuesta de las pruebas es, por excelencia, acto de las partes. A ellas compete afirmar los hechos, fundamento del derecho subjetivo invocado, así como convencer al juzgador acerca de su ocurrencia, haciendo uso del lenguaje de pruebas"; mientras que "al juzgador no compete, sin embargo, determinar la realización de pruebas de oficio, en sustitución de la iniciativa de las partes" y precisa que si "la parte omite el deber de probar, no se puede hablar de producción probatoria del juzgador. Es lícita la determinación de diligencia para esclarecer las dudas siempre que esto no implique producción de prueba que podría ser y no fue propuesta por la parte a quien incumbía la carga de probar (p.255-257).

Ahora bien, con el Desarrollo del Derecho Procesal, como anota Hurtado (2009) se le otorgó al juez civil facultades de oficio, tales como, impulso de oficio y aportación de medios de prueba por deficiencias de las partes, entre otras (p. 595); sin embargo, como señala Echeandía (2012), esto no significa que:

Se le haya privado a las partes del derecho a aportar pruebas, e incluso, sin que deje de existir la carga de la prueba, desde el momento en que se corre el riesgo de su falta si el juez no las decreta oficiosamente, por desconocerla o por falta de iniciativa y sin eliminar la necesidad de la demanda y la congruencia de la sentencia, por lo que el proceso civil totalmente dispositivo no existe ya (p. 73-74).

Como se aprecia si bien en el proceso civil se han introducido diversas facultades al juez a fin de que cumpla con su función de administrar justicia, ello no significa que las partes no se encuentren obligadas a aportar las pruebas para demostrar sus afirmaciones, lo cual constituyó desde su origen base del principio dispositivo, por lo que para fines del presente trabajo, se entenderá como dicho principio, justamente aquél en el cual la carga de la prueba recae sobre las partes del proceso.

\section{- En el ámbito administrativo}


En España, en materia administrativa, una vez abierto el periodo probatorio, por la contradicción de los hechos o la naturaleza del procedimiento lo exija ${ }^{7}$, es cuando entran en juego las reglas generales sobre la carga de la prueba, la cual se resumen en el viejo adagio incumbit probatio qui dixit, non qui negat, es decir, la regla según la cual le corresponde al actor la prueba de los hechos constitutivos de su pretensión, mientras que al demandado incumbe la prueba de los impeditivos y de los extintivos, positivado en el artículo $1214^{\circ}$ del Código Civil. Solo dentro del periodo probatorio y sobre la base de la no aceptación previa por la Administración de las alegaciones del interesado. (Garcia Enterría y Tomás-Ramón, 2006, p. 1436).

Como podemos apreciar, en el derecho administrativo español, una vez abierto el periodo de prueba, se aplican las reglas de distribución de la carga de la prueba del Derecho Civil. A diferencia de nuestra legislación, que establece en el artículo $162^{\circ}$ de la LPAG, que la carga de la prueba se rige por el principio de impulso de oficio.

Ahora, si bien es indudable que la institución de la prueba y el proceso, donde ella se desarrolla, tienen un desarrollo más avanzado en sede jurisdiccional, también lo es, que el derecho administrativo, tiene una naturaleza y fines distintos.

En palabras de los profesores españoles, Garcia de Enterría y Tomás-Ramón (2006) el proceso judicial y el procedimiento administrativo comparten y se distinguen en:

Entre el proceso judicial y el proceso administrativo existen si semejanzas indudables, dada la pertenencia de ambas instituciones a un tronco común, pero hay también profundas diferencias como consecuencia necesaria de la diversa naturaleza de los fines que una y otra sirven, y sobre todo, de la distinta posición y carácter de los órganos cuya actividad disciplinan.

El proceso tiene como fin esencial la averiguación de la verdad y la satisfacción de las pretensiones ejercitadas por las partes mediante la decisión de una instancia neutral e

\footnotetext{
${ }^{7}$ La novedad más importante de la Ley [Ley de Procedimiento Administrativo de 1958] radica, sin duda, en la configuración de un trámite de prueba de obligado cumplimiento en los supuestos expresamente previstos: cuando la Administración "no tenga por cierto los hechos alegados por los interesados" o "la naturaleza del procedimiento la exija", con lo que la Ley hace una importante distinción, entre aquellas pruebas que pueden desarrollarse con ocasión del cumplimiento de los diversos trámites procedimentales y las que necesariamente han de practicarse en el curso de ese específico periodo de prueba. Las únicas, pero significativas, palabras que la Exposición de motivos de la Ley dedica a la prueba: "se regula afirma- con gran amplitud y, a fin de garantizar debidamente los derechos de los interesados, se impone ahora un periodo de prueba cuando la Administración no tenga por cierto los hechos aducidos o lo exija la naturaleza del procedimiento". (Barrero, 2006, p.139)
} 
independiente de ellas, el Juez o Tribunal. En cambio, el procedimiento administrativo, si bien constituye una garantía de los derechos de los administrados, no agota en ello su función, que es, también, y muy principalmente, la de asegurar la pronta y eficaz satisfacción del interés general mediante la adopción de las medidas y decisiones necesarias por los órganos de la Administración, interpretes de ese interés y, al propio tiempo parte del procedimiento y arbitro del mismo. (p. 1378)

De otro lado, en un estudio más acucioso, el profesor español Barrero (2011), postula la tesis de la autonomía de la prueba en el procedimiento administrativo respecto de la prueba procesal, ensaya un análisis distinto, "tomando como punto de partida, el examen comparativo entre el proceso judicial y el procedimiento administrativo, con incidencia en la prueba, resultando de ella, similitudes y diferencias existentes entre la prueba que se desarrolla en una y otra vía”. (pp. 62-63) que a continuación se detallan:

- La diferente composición subjetiva de los procesos judiciales y los procedimientos administrativos

El procedimiento administrativo cuenta, como es notorio, con una composición subjetiva muy diferente a la del proceso. Si en este existen dos partes que comparecen en posición de igualdad ante un tercero imparcial, el procedimiento administrativo se desarrolla por lo general, entre el interesado y la Administración que, en clásica expresión, actúa de "Juez y parte" al propio tiempo, tramita el procedimiento y resuelve. Dato, como ha de verse, de importantes repercusiones sobre la prueba por cuanto de inmediato va a indicarse.

\section{○ Principio de igualdad de partes}

Administración y administrado no se encuentran, ni en general ni en el procedimiento administrativo particular, en una posición de igualdad ante el Derecho; su "status" aparece expresamente definido por el ordenamiento jurídico y se compone de una serie de prerrogativas, a favor normalmente de la Administración, y de garantías de beneficio, en el común de los casos, del administrado, que impregnan todo el actuar de la Administración Pública y que otorga a sus relaciones con terceros un marcado carácter diferenciador respecto de las que en general se entablan entre sujetos jurídicos privados. En síntesis, Administración y administrado no se encuentran en el procedimiento administrativo en una posición de igualdad al modo en el que se hayan 
las partes del proceso; de ahí la dificultad en numerosos casos, para la aplicación al procedimiento administrativo de las reglas procesales de la prueba que tiene justamente en la garantía de ese principio uno de sus presupuestos básicos.

\section{○ La garantía de la imparcialidad}

En el procedimiento administrativo (...) no puede afirmarse que estén presentes las garantías de imparcialidad e independencia propias de los órganos judiciales y consustanciales a la prueba procesal. (...) En conclusión, difícilmente puede explicarse la actividad de acreditación de hechos que se desarrolla en el procedimiento administrativo desde unos esquemas, como son los del proceso, en los que los sujetos que intervienen ocupan posiciones jurídicas muy diferentes y difícilmente puede aplicársele; por consiguiente, un sistema jurídico, como es el establecido en la LECiv, que corresponde precisamente a ese esquema.

- El importante contraste entre los principios que presiden el desarrollo de los procesos civiles y de los procedimientos administrativos. Principio dispositivo/principio de oficialidad

También los principios que gobiernan el desenvolvimiento de los procesos civiles y de los procedimientos administrativos establecen profundas diferencias entre unos y otros que, igualmente, dejan sentir sus consecuencias en el ámbito de la prueba. De entre ellos merecen singular mención los principios que rigen el desenvolvimiento de los procesos judiciales civiles y de los procedimientos administrativos, el principio dispositivo y el de oficialidad, respectivamente.

Si el proceso civil descansa en los principios de aportación de parte y dispositivo en cuya virtud, y con carácter general, el Juez se pronuncia exclusivamente sobre los hechos aportados por las partes y con base en las pruebas que ellas mismas le ofrecen, el procedimiento administrativo se rige por el principio de oficialidad (...). Ello significa en último término que la Administración, a diferencia del Juez civil, cuenta con unos poderes, al tiempo que con una carga, en la prueba de los hechos absolutamente 
desconocidos en el proceso civil y que abogan, por el establecimiento de un régimen propio para la "prueba administrativa" (...).

- Distinta estructura de los procesos judiciales y de los procedimientos administrativos. Sus repercusiones sobre la garantía del principio de contradicción

El procedimiento administrativo se desarrolla de una forma muy distinta a como lo hacen los procesos judiciales, lo que significa, entre otras cosas, que, aun cuando en ciertos casos pueden responder a un mismo objetivo, su consecución va a procurarse de una forma muy diferente. Es lo que señaladamente ocurre con la garantía del principio de contradicción, consustancial tanto al proceso judicial como al procedimiento administrativo $(\ldots)$.

En su proyección concreta sobre la prueba, el principio de contradicción se manifiesta tanto en el derecho del interesado a aducir las pruebas que considere necesarias para la defensa de sus pretensiones, como en la posibilidad de participar efectivamente en su desarrollo. Este es su significado último tanto en los procesos judiciales como en los procedimientos administrativos (...).

\section{- Fin del proceso y del procedimiento administrativo}

Interesa reparar, igualmente que el proceso judicial y los procedimientos administrativos sirven a fines diferentes. El primero, a la adopción de la resolución justa en Derecho que ponga fin a una contienda entre las partes; el segundo, a la elección de aquella decisión que, siendo conforme al ordenamiento jurídico, mejor satisfaga los intereses generales. De esta forma cabe afirmar que si en el proceso los hechos se demuestran a fin de que pueda determinarse cuál es la solución conforme al ordenamiento jurídico en el litigio que enfrenta a dos sujetos; en el procedimiento administrativo se verifica su existencia no sólo para dilucidar cuál es la consecuencia jurídica que les corresponde, sino para determinar, en función, precisamente, de los hechos probados, la solución más favorable a la satisfacción de los intereses generales. (p. 63-66)

\section{- En el ámbito tributario}


Al revisar las reglas de distribución de la carga de la prueba, en materia tributaria, en la legislación comparada, encontramos que el Centro Interamericano de Administraciones Tributarias (CIAT), postula en el Modelo de Código Tributario 2006, en el artículo $80^{\circ}$ que en los procedimientos tributarios, quien haga valer su derecho deberá probar los hechos constitutivos del mismo. Esta obligación se entiende cumplida si se designan, de modo concreto, los elementos de prueba en poder de la Administración Tributaria. Como se puede apreciar, este artículo consagra el principio general de quien alega la ocurrencia de un hecho un hecho, debe probarlo.

El profesor Villanueva nos ilustra que en el derecho comparado, "un primer sistema es que la carga de la prueba es compartida, es decir, la Administración y el contribuyente están obligados en este caso a probar. Carga que se distribuye en merito al principio dispositivo, principio adoptado en Dinamarca, Bélgica, España, Finlandia, Holanda y Rusia”. (Sociedad Nacional de Minería, Petróleo y Energía [SNMPE], 2015, p. 66)

En España, en el artículo $105^{\circ}$ de la Ley General Tributaria, Ley 58/2003, de 17 de diciembre (LGT), se establece una regla general de distribución de la carga de la prueba, la cual señala que: 1 . En los procedimientos de aplicación de los tributos quien haga valer su derecho deberá probar los hechos constitutivos del mismo. 2. Los obligados tributarios cumplirán su deber de probar si designan de modo concreto los elementos de prueba en poder de la Administración Tributaria.

Como viene reconociendo la jurisprudencia española, se trata de una regla legal que impone a cada parte la prueba del hecho constitutivo de su pretensión, en términos afines a las tradicionales doctrinas civilistas ${ }^{8}$, en cuya virtud corresponde al actor o demandado reconviniente la carga de la prueba de los hechos constitutivos y al demandado o actor reconvenido la de los hechos impeditivos, extintivos y excluyentes. Asimismo, encontramos "en la jurisprudencia española que es habitual que la Administración pruebe la recepción o la existencia de renta y el contribuyente la realidad o efectividad del gasto"9. (Rodriguez-Bereijo, 2012, pp.16-17)

\footnotetext{
${ }^{8}$ Nacidas de los antiguos artículos $1214^{\circ}$ y siguientes del Código Civil y hoy recogidas con mayor precisión en los incisos 2 y 3 del artículo $217^{\circ}$ de la Ley de Enjuiciamiento Civil (LEC). (RodriguezBereijo, 2012, pp.16-17)

${ }^{9}$ Sentencia el Tribunal Superior de Justicia de castilla y León, de 25 de febrero de 1992 y Sentencia del Tribunal Supremo de 11 de junio de 1998 (NFJ006776).
} 
Nuestro Código Tributario no establece reglas sobre la carga de la prueba, por lo que ante la falta de dichas reglas corresponde aplicar la Norma IX del Título Preliminar del Código Tributario, la cual establece que en lo no previsto por dicho código o en otras normas tributarias, podrán aplicarse normas distintas, siempre que no se les opongan, ni las desnaturalicen.

Si dirigimos nuestra mirada a las resoluciones emitidas por el Tribunal Fiscal, observaremos que el citado tribunal, en merito a la Norma IX ha basado su razonamiento, en distintas normas supletorias, y en reiteradas ocasiones ha señalado que de acuerdo al artículo $196^{\circ}$ del Código Procesal Civil, la carga de la prueba corresponde a quien afirma hechos que configuran su pretensión, o a quien los contradice alegando nuevos hechos. ${ }^{10}$

Moreno (2014) nos hace notar que, en el ámbito tributario, se ha interiorizado que tenemos que recurrir a la teoría de la carga de la Prueba desarrollada en el Código Procesal Civil, y advierte que ahí hay una grave distorsión teórica, basado en:

Dicho principio está recogido en un principio dispositivo, esto es lo que las pruebas al proceso es lo que existe en el expediente y es respecto a lo cual el juez se pronunciará. El juez o el juzgador, en este caso el resolutor, no realiza ninguna actividad probatoria.

En el caso del Derecho Administrativo, el principio es totalmente alejado a lo que vendría a ser el Código Procesal Civil. El instructor, el resolutor, tiene una actividad probatoria activa, y esto por el principio de impulso de oficio recogido del 162 de la Ley de Procedimientos Administrativo General.

Esto quiere decir que el resolutor es quien tiene la obligación de activar los medios probatorios: muy parecido a lo que vendría a ser el procedimiento de instrucción legal. O sea, más nos parecemos al procedimiento administrativo y al proceso probatorio penal que al Código Procesal Civil.

Por eso cuando las premisas parten de un postulado erróneo podemos llegar por lo general a conclusiones erróneas. (p. 58)

Como se aprecia, la falta de regulación de las reglas de la carga de la prueba conlleva a que el Tribunal Fiscal aplique supletoriamente las normas del Derecho Procesal Civil en la resolución de las controversias tributarias, posición con la cual no se encuentra conforme parte de la doctrina nacional.

${ }^{10}$ RTF No 0033-3-2000, 06810-3-2003, 07281-3-2003, 02303-1-2004, 12609-8-2011, 20274-9-2012, entre otras. 


\subsection{Principio de facilidad probatoria}

\section{- En el ámbito procesal}

Según Donaires (2014), existe una tendencia de "flexibilización de las reglas clásicas de distribución de la carga de la prueba, bajo la influencia de la doctrina de las cargas probatorias dinámicas" (p. 3).

Para el reconocido maestro argentino Peyrano" "más allá del carácter de actor o demandado, en determinados supuestos la carga de la prueba recae sobre ambas partes, en especial sobre aquella que se encuentre en mejores condiciones para producirla". Asimismo, sostiene que "esta nueva teoría no desconoce las reglas clásicas de la carga de la prueba, sino que trata de complementarla o perfeccionarla, flexibilizando su aplicación”. (como se citó en Donaires, 2014, p.4-5).

Para Avendaño "se trata de trasladar la verificación de los hechos en razón de la situación favorable en la cual se halla la parte para acreditar la realidad de los mismos, por cuanto dispone de los medios y argumentos que resultan aptos para desmostarlos" (como se citó en Donaires, 2014, p.3). De otro lado, Campos (2012) señala que la teoría de las cargas probatorias dinámicas:

Rompe la regla rígida que sostiene todo el aparato distributivo de la carga de la prueba en nuestro sistema procesal, regla según el cual "quien afirma, debe probar", proponiendo más bien que, de manera excepcional, en casos de prueba difícil o imposible, la carga de la prueba recae en el sujeto del proceso que se encuentre en mejores condicione, en mayor aptitud para proporcionar el material probatorio

\footnotetext{
${ }^{11}$ La doctrina de las cargas probatorias dinámicas, ha sido puesta en relieve en nuestro continente por el maestro PEYRANO, en coautoría con CHIAPPINI, a partir del año 1984, año en el cual publicaron en Argentina, su aporte doctrinal "Lineamientos de las cargas probatorias dinámicas" en El Derecho, tomo 107, pág. 1005.

${ }^{12}$ Para dicho autor, el origen de esta teoría data del año 1823 (afirmación discrepante respecto de los autores que sostiene que esta teoría tiene su origen en la Republica de Argentina); y que habría sido expuesta por el destacado jurista y pensador ingles Jeremías BENTHAM (conocido como el padre del utilitarismo). Este autor habría denunciado el abuso que tiene lugar por encontrase la carga probatoria sobre quien demanda, y habría propuesto que la carga pesara sobre quien esté en mejores condiciones de probar.

Sin perjuicio de ello, AVENDAÑO, reconoce que en nuestro continente, la idea de la carga dinámica de la prueba surgió como consecuencia de un complejo caso de responsabilidad médica por mala praxis en Argentina (Caso "Pinheiro, Ana María y otros con Instituto de Servicios Sociales para el personal Ferroviario", Corte Suprema de Justicia de la Nación, Buenos Aires, Argentina, 10 de diciembre de 1997); y gracias a las construcciones teóricas formuladas por PEYRANO.
} 
vinculado a la materia controvertida, independientemente de que si es el actor o el demandado que afirmó el hecho. (p. 203)

Bermúdez sostiene que "es una regla que permite al juez en el caso concreto determinar cuál de las partes debe correr con las consecuencias de la falta de prueba de determinado hecho, en virtud a que a ésta le resulta más fácil suministrarla" (como se citó en donaires, 2014, p.5)

En la jurisprudencia, en algunas resoluciones, se ha introducido la Teoría de las Carga Probatorias Dinámicas ${ }^{13}$, la cual constituye "un medio para flexibilizar, de manera excepcional, la rigidez de la regla general de distribución de la carga probatoria recogida en el artículo $196^{\circ}$ del Código Procesal Civil” (Campos, 2012-2013, p.201)

\section{- En el tributario}

El profesor Villanueva nos precisa que "en el derecho comparado, en Alemania y Suecia se dice que los hechos deben ser probados por la parte que pueda obtener más fácilmente la prueba”. (SNMPE, 2015, p. 66)

De la revisión de la jurisprudencia tributaria, el Tribunal Fiscal, en algunas resoluciones, ha introducido la Teoría de las Carga Probatorias Dinámicas ${ }^{14}(\text { TCPD })^{15}$.

El ex vocal del Tribunal Fiscal Moreano (2015) postula que en un procedimiento de fiscalización "no cabe invertir la carga de la prueba de los administrados, bajo la

\footnotetext{
${ }^{13}$ RTF No $18397-10-2013$, entre otras.

${ }^{14}$ RTF No $18397-10-2013$.

15 "Son dos los sistemas que regulan la prueba judicial: el sistema dispositivo y el inquisitivo; el primero supone, en esencia, que la actividad probatoria corresponde únicamente a las partes, mientras que en el segundo dicha actividad probatoria no es exclusiva de las partes sino el Juez tiene un rol trascendente, pudiendo ordenar la actuación de medios probatorios de oficio a fin de verificar lo afirmado por las partes dentro del proceso. (...) Así el sistema dispositivo es parte del sistema procesal privatístico, mientras que el sistema inquisitivo se instaura de una concepción del proceso conocida como sistema procesal publicístico. (...) Efectuada tal diferenciación de sistemas procesales, tenemos que la teoría de las cargas probatorias dinámicas se ubica en la concepción publicista del proceso, ahí donde prima el sistema inquisitivo, donde el papel del juez es activo y goza de amplias facultadas y poderes como director del proceso, para la reconstrucción artificial de los hechos del proceso y establecer quién tiene la razón llegando a la verdad real procesal.

La TCPD rompe la regla rígida que sostiene todo el aparato distributivo de la carga de la prueba en nuestro sistema procesal, regla según la cual "quien afirma, debe probar", proponiendo más bien que, de manera excepcional, en casos de prueba difícil e imposible, la carga de la prueba recae en el sujeto del proceso que se encuentra en mejores condiciones, en mayor aptitud para proporcionar el material probatorio vinculado a la materia controvertida, independientemente de si es el actor o el demandado que afirmó el hecho". (Campos, 2012-2012, pp. 202-203)
} 
aplicación de la carga probatoria dinámica, dado que al ser un procedimiento oficioso, como regla general, la carga le corresponde a la Administración”. (p. 25)

Conforme se ha expuesto, el Tribunal Fiscal ha aplicado en la resolución de controversias tributarias el principio de facilidad probatoria, sin embargo, parte de la doctrina nacional no se encuentra de acuerdo con ello debido a que consideran que la Administración Tributaria es la que tiene la carga de la prueba en el procedimiento de fiscalización.

\subsubsection{Carga de la Administración Tributaria}

\subsection{Principio inquisitivo}

\section{- En el ámbito procesal}

Cabe anotar que con el desarrollo del Derecho Procesal se determinó que el proceso en general tenía un fin público, esto es, la administración de justicia para mantener el orden social.

Así, según Echeandía (2012):

La doctrina universal ha sustituido la concepción privatista del proceso por la publicista, según la cual, en el proceso civil se aprecia el ejercicio de la jurisdicción del Estado, tan importante y tan profundo interés público como en el proceso penal, e igualmente le señala un fin de interés público o general; la recta aplicación de la ley material y la administración de justicia para la paz y la tranquilidad sociales. Así, nadie discute la conveniencia y aun la necesidad de imponer el principio inquisitivo en materias penales; también para los procesos laboral y fiscal se admite sin objeciones. (pp.71, 74-75).

En este punto, es importante resaltar la precisión de Michelli (1989), según la cual:

La doctrina de la carga objetiva ha sacado notable partido de la comprobación de que también en procesos en los que predomina el principio inquisitorio, sin embargo, el juez debe juzgar en todos los casos, y se ha creído precisamente encontrar en el fenómeno una justificación para el concepto (considerado jurídico) de carga objetiva. (p.222).

A título ilustrativo, cabe anotar que según explica Falcón (2009) respecto a la carga de la prueba en el proceso penal, inquisitivo por excelencia, considerando el principio 
rector "indubio pro reo", la tesis positiva respecto a la carga de la prueba "ha sido raramente sostenida", siendo la tesis negativa la que cuenta con aceptación mayoritaria, basándose que en virtud del mencionado principio, "el acusado no tiene carga probatoria alguna y goza de una situación jurídica que no debe ser construida sino destruida". Por su parte, la teoría intermedia señala que "al tribunal no le corresponde la carga, sino el deber de investigar la verdad, pero el imputado se ve sometido a la carga probatoria cuando el acusador invoca en su contra ciertas pruebas producidas en el sumario, y en la defensa se pretende enervarla". No obstante, Maier se opone a dicha tesis señalando que "el deber del acusador público no reside en verificar ese hecho punible, sino, antes bien, en investigar la verdad objetiva acerca de la hipótesis delictual objeto del procedimiento, tanto en perjuicio como a favor del imputado, deber similar al que pesa sobre el tribunal. Y ambos están ligados por la regla que les exige que, si no obtienen la certeza, se deben pronunciar a favor del imputado" (p.327-332)

\section{- En el ámbito administrativo}

Ahora bien, como se ha expuesto el principio inquisitivo en material procesal está sustentado en las facultades dadas al juez para requerir pruebas adicionales y complementarias a las presentadas por las partes para dilucidar el hecho controvertido, en esa línea de criterio, dicho principio ha sido aplicado también a los procedimientos administrativos, regidos por los principios de legalidad, impulso de oficio y verdad material.

\footnotetext{
Al respecto, Del Padre (2012), anota:

Los procesos administrativos son orientados por el principio inquisitorio o de la oficialidad, de modo que, a pesar de la iniciativa, necesaria para instaurar el contencioso, quepa al contribuyente, el desarrollo procesal no depende únicamente de los actos de éste. Así anota que de los principios constitucionales tributarios, como los de la legalidad y de la tipicidad, así de la autorización para que la Administración realice, ella misma, el control de legalidad de sus actos, la producción probatoria puede ser efectuada por iniciativa de la autoridad juzgadora, por lo que existe diferencia entre el proceso judicial y el administrativo tributario, toda vez que el primero está orientado por el principio dispositivo y el segundo por el inquisitivo. Los principios que orientan la producción de la prueba en el proceso administrativo tributario es además del principio inquisitivo, el principio del debido procesal legal, entre otros (pp. 257-271).
} 
A continuación, desarrollaremos los principios que regulan la actividad probatoria en el procedimiento administrativo general a fin de explicar cómo se han establecido las reglas de la carga de la prueba en base a los mismos en dicho procedimiento y cómo la doctrina y legislación tributaria han sustentado dichas reglas para el caso específico del procedimiento de fiscalización.

\section{Principio de oficialidad}

Conviene anotar que el principio inquisitivo es el principio general aplicable a los procesos judiciales así como el de oficialidad a los administrativos, según se ha explicado previamente.

Para Garcia de Enterría y Tomás-Ramón (2006), la oficialidad significa que:

La Administración ésta específicamente obligada a desarrollar la actividad que sea necesaria para llegar a la decisión final, sin necesidad que sea excitada en ese sentido por los particulares, pues a diferencia de lo que ocurre en el ámbito civil donde, por regir el principio dispositivo, se entiende que el proceso es cosa de las partes, de quienes depende, en consecuencia su progresión. Añaden a su vez los profesores españoles que la impulsión de oficio, que responde a las exigencias propias del interés público que el procedimiento administrativo pone en juego, da a este un acusador carácter inquisitorial: la Administración, gestora del interés público, está obligada a desplegar por sí misma, ex officio, toda la actividad que sea necesaria para dar adecuada satisfacción a ese interés, sea cual sea la actitud, activa o pasiva, que puedan adoptar los particulares que hayan comparecido en el procedimiento. (pp. 1406-1408).

Por su parte, Barrero (2006) anota que dicho principio se encuentra consagrado en la LRJ-PAC, conforme al cual el procedimiento se impulsará de oficio en todos sus trámites y los actos de instrucción necesarios para la determinación, conocimiento y comprobación de los hechos en virtud de los cuales deba pronunciarse la resolución, se realizarán de oficio por el órgano que tramite el procedimiento. "Ello significa en último término que la Administración, a diferencia del Juez civil, cuenta con unos poderes, al tiempo que con una carga, en la prueba de los hechos absolutamente desconocidos en el proceso civil”. (p.64).

En nuestra legislación el principio de oficialidad se encuentra regulado como el Principio de impulso de oficio en el numeral 1.3 del artículo IV del Título Preliminar 
de la LPAG, según el cual: "las autoridades deben dirigir e impulsar de oficio el procedimiento y ordenar la realización o práctica de los actos que resulten convenientes para el esclarecimiento y resolución de las cuestiones controvertidas.

En la misma línea, Morón (2015), entiende que el principio de oficialidad a las autoridades les corresponde:

Impulsar, dirigir y ordenar cualquier procedimiento administrativo sometido a su competencia hasta esclarecer las cuestiones involucradas, aún cuando se trate de procedimientos iniciados por el administrado o por la propia autoridad. Ahora bien, el deber de oficialidad no excluye la posibilidad de impulso propio, de colaboración o de gestión del que goza el administrado para promover el trámite.

La oficialidad impone a los agentes cumplir las siguientes acciones concretas:

- Iniciar el procedimiento.

- Impulsar el avance del procedimiento, solicitando cuantos documentos, informes, antecedentes, autorizaciones y acuerdos sean necesarios, incluso si fuere contra el deseo del administrado, cuando sean asuntos de interés público (como por ejemplo, en caso de desistimiento y abandono).

- Remover los obstáculos del trámite.

- Instruir y ordenar la prueba.

- Subsanar cualquier error u omisión que advierta en el procedimiento.

El deber de oficialidad no sólo exige ciertas acciones positivas por parte del funcionario sino algunas obligaciones de no hacer. En tal virtud, la Administración no puede proceder al archivo de un expediente sin haberlo resuelto (expresa o tácitamente) y aun en el caso que el procedimiento sea concluido de manera atípica (abandono, desistimiento, etc.) amerita una resolución expresa que así lo establezca. (p. 73)

\section{Principio de verdad material}

El Principio de verdad material se encuentra recogido en el numeral 1.11. del artículo IV del Título Preliminar de la LPAG, según el cual en el procedimiento, la autoridad administrativa competente deberá verificar plenamente los hechos que sirven de motivo a sus decisiones, para lo cual deberá adoptar todas las medidas probatorias necesarias autorizadas por la ley, aun cuando no hayan sido propuestas por los administrados o hayan acordado eximirse de ellas. 
Por el principio, bajo estudio, Morón (2015) señala que:

Por el principio de verdad material o verdad jurídica objetiva, las autoridades instructoras de los procedimientos tienen la obligación de agotar de oficio los medios de prueba a su alcance para investigar la existencia real de hechos que son la hipótesis de las normas que debe ejecutar y resolver conforme a ellas, para aplicar la respectiva consecuencia prevista en la norma. El principio se sustenta en que en los procedimientos administrativos no se trata de resolver conflictos intersubjetivos como en los procedimientos arbitrales o judiciales, sino de decidir directamente asuntos de interés público por su contenido en los que la aplicación de la norma a los casos concretos no puede depender de la voluntad del particular de no aportar el material probatorio pertinente.

En aplicación de este principio, las actuaciones probatorias de las autoridades deben estar dirigidas a la identificación y comprobación de los hechos reales producidos y constatar la realidad, independientemente de cómo hayan sido alegadas y, en su caso, probadas por los administrados participantes en el procedimiento. En sentido inverso, el principio pretende que la probanza actuada en el procedimiento permita distinguir cómo en la realidad ocurrieron los hechos (verdad real o material) de lo que espontáneamente pueda aparecer en el expediente de acuerdo a las pruebas presentadas por los administrados (verdad formal o aparente), para dar la solución prevista en la ley. (p. $81)$.

A continuación corresponde explicar cómo se han establecido las reglas de la carga de la prueba en el procedimiento administrativo general sustentándose en los principios antes expuestos.

Guzmán (2005) anota sobre la carga de la prueba en el citado procedimiento:

Siendo la actividad probatoria medular en la ejecución de su instrucción, dicha actividad le corresponde fundamentalmente a la entidad, estableciéndose entonces el principio de que la carga de la prueba, es decir, la obligación de probar los fundamentos que sustentan la decisión le corresponde a la Administración y no a los administrados, sin perjuicio de permitirles a estos acreditar los hechos que alegan. No es que los particulares no deban probar su pretensión, sino que la negativa de la Administración debe estar debidamente acreditada (p.134).

En el mismo sentido, Brewer (2003), revisando la Ley de Perú y de Honduras, anota que siendo el procedimiento administrativo asunto de la Administración, la carga de la prueba, ante todo, es también responsable de aquella (p.135). 


\section{- En el ámbito tributario}

¿Y en que se basan los ordenamientos que indican que la carga de la prueba corresponde a la Administración Tributaria? Básicamente en el principio de impulso de oficio y el principio de verdad material. Es decir, la Administración está en este caso obligada a investigar todos los hechos relevantes para gravarlos. (SNMPE, 2015, p. 67)

En relación a la carga de la prueba, Del Padre (2012) concluye lo siguiente:

No tiene la autoridad administrativa mera carga de probar el hecho jurídico o el ilícito tributario que da soporte a sus actos, sino verdadero deber, como es manifestado por Souto Maior Borges; "El Fisco, por lo tanto, tiene el deber -no la carga- de verificar la ocurrencia de la situación jurídica tributaria conforme a ella se desarrolla en el mundo fáctico, con independencia de las llamadas pruebas pre-constituidas o presunciones de cualquier género (...). Si el procedimiento administrativo es, en principio, indisponible, en él no cabe la inserción de la categoría jurídica en que la carga consiste". La construcción del hecho en el antecedente de norma administrativo-tributaria individual y concreta, por medio de las pruebas admitidas, constituye la propia motivación del acto administrativo, elemento sin el cual éste no subsiste

Efectuada la determinación o el acto de aplicación de penalidad según los moldes prescritos en el ordenamiento, pasa a ser del contribuyente la carga de la contraprueba. Instaurado el contencioso administrativo, el discurso jurídico asume el carácter de una discusión, enriquecida por acciones lingüísticas orientadas para la persuasión y convencimiento, en que a cada parte incumbe justificar sus afirmaciones. Así, debidamente probado el hecho enunciado por el Fisco o por el contribuyente, las alegaciones que pretendan desconstituirlo deben, igualmente, estar fundadas en elementos probatorios. Todo, en el ámbito de la regla según la cual la carga/deber de la prueba cabe a quien alega (pp.282-285).

En similar posición, Folco (2012) anota lo siguiente:

En la ponderación de la actividad administrativa no puede hablarse en sentido técnico de la carga de la prueba tributaria, por cuanto la administración debe buscar la verdad material, aunque el contribuyente no haya probado sus alegaciones, teniendo en consideración que la pertenencia de la administración al moderno Estado de Derecho exige de ella el máximo esfuerzo probatorio.

El Tribunal Fiscal de la Nación recoge el criterio expuesto por Fenech, afirmando que el principio inquisitivo puede complementarse con la existencia de la carga de la 
prueba, en tanto la actividad del juez no puede evitar en todos los casos la incertidumbre sobre los hechos alegados y no suficientemente probados, por tanto el resultado desfavorable de la falta de la prueba habrá de recaer, necesariamente, sobre la parte que invocó el hecho incierto. Con mayor razón cuando las partes ni siquiera han intentado demostrar sus dichos, lo que de ningún modo puede suplirse con las facultades de investigación inherentes al tribunal.

Así, la jurisprudencia ha declarado que no se desconoce que en la instancia administrativa el particular tiene un interés personal y directo, que lo lleva lógicamente a actuar con subjetividad en defensa de los derechos que cree avasallados por la actuación administrativa, necesarios para esclarecer la verdad de los hechos que se le plantean.

Por su parte, el más alto Tribunal de la Nación Argentina ha establecido que en materia de determinaciones impositivas se admite la sustantividad de reglas distintas sobre la carga de la prueba con relación a las que se aplican en los demás juicios (pp. 11-12).

En el derecho comparado, En Francia, por ejemplo, no existe una norma general sobre la carga de la prueba y, en particular, no hay división entre los ingresos y los costos. En 1987 se trató, por ley, de establecer un principio según el cual la carga de la prueba tenía que ser asumida por la Administración Tributaria. Pero la regla no estaba claramente establecida en el texto de la ley, por lo que los Tribunales Tributarios consideraron que no había obligación de cumplirla. En cualquier caso, este principio no era realista, en la medida en que en un sistema declarativo la parte principal de la verdad sólo es conocida por el contribuyente. Por lo tanto, este último tiene que soportar la parte más importante de la carga de la prueba, situación que se puede verificar en los hechos. La jurisprudencia demuestra que, la mayor parte del tiempo, los contribuyentes realmente soportan la carga de la prueba. (Meussen et al., 2013, p. 119).

De lo expuesto, se verifica que existe una tendencia a considerar que de acuerdo a los Principios Administrativos de Impulso de Oficio y el Principio de Verdad Material, así como el carácter indisponible del procedimiento de fiscalización, la Administración Tributaria no tendría carga de la prueba alguna sino mas bien el deber de realizar las actuaciones probatorias necesarias para sustentar sus actos; sin embargo, se reconoce también que el contribuyente tiene una carga de la prueba en dicho procedimiento, a fin de no ser perjudicado por la consecuencia que se genere por la falta de certeza del hecho desconocido en el mismo. 


\subsubsection{Carga de la prueba del contribuyente}

¿En que se basan los ordenamientos que dicen que la carga de la prueba es de responsabilidad del contribuyente? "En el principio de autodeterminación. Los tributos se autoliquidan por parte de los contribuyentes. Los contribuyentes presentan la declaración, presentan su determinación y, por tanto, están obligados a probar la veracidad de su declaración". (SNMPE, 2015, p. 66)

\subsection{Principio autodeterminación}

Calvo (2002) señala que la declaración tributaria "es una manifestación de conocimiento obligatoria sobre un hecho tributario realizada por un sujeto pasivo ante la Administración Pública, que puede ser rectificada. Los efectos de dicha declaración son el cumplimiento de un deber impuesto por una norma jurídica”. (p. 266-267).

Por su parte Sainz de Bujanda (1991) agrega lo siguiente:

La declaración se persigue la colaboración del sujeto pasivo mediante una manifestación de voluntad y de conocimiento que proporciona a la Administración una serie de datos necesarios para la determinación de la existencia de la obligación tributaria. Desde el punto de vista del contribuyente, la declaración se convierte en máxima garantía de que se liquida un tributo con arreglo a derecho, ya que mediante ella, el sujeto pasivo podrá hacer llegar a la Administración una seria de aspectos, de datos, que, desconocidos previamente por ésta, pueden tener una incidencia decisiva en la obligación tributaria. De allí que la declaración se erija en institución básica de los sistemas liquidadores respetuosos del principio de capacidad contributiva (p. 313).

En el mismo sentido, el artículo $88^{\circ}$ del Código Tributario define la declaración tributaria como la manifestación de hechos comunicados a la Administración Tributaria en la forma y lugar establecidos por Ley, Reglamento, Resolución de Superintendencia o norma de rango similar, la cual podrá constituir la base para la determinación de la obligación tributaria. Asimismo se establece que los deudores tributarios deberán consignar en su declaración, en forma correcta y sustentada, los datos solicitados por la Administración Tributaria. Y que se presume sin admitir prueba en contrario, que toda declaración jurada es jurada. 
Asimismo, el numeral 1 del artículo $176^{\circ}$ del Código Tributario establece como una infracción relacionada con la obligación de presentar declaraciones y comunicaciones, aquélla referida a no presentar las declaraciones que contengan la determinación de la obligación tributaria dentro de los plazos establecidos.

En el derecho comparado, "este principio se sigue en Noruega y en Grecia". (SNMPE, 2015, p. 66). En Grecia, por ejemplo, la presentación de una declaración tributaria es el cumplimiento de una obligación de derecho público, a través de la cual los contribuyentes informan a la Administración Tributaria los datos necesarios para la determinación de sus impuestos (Ingresos brutos y gastos relevantes). Por esta razón, su omisión, presentación tardía o contenido inexacto de la declaración tributaria resultan en la imposición de sanciones. La presentación de la declaración tributaria no es simplemente la presentación de datos que son cruciales para las obligaciones tributarias, sino también un título de certificación fiscal. Esto significa que, al menos inicialmente, la declaración tributaria es considerada veraz y la Administración Tributaria debe determinar el impuesto de acuerdo a la información declarada. Al mismo tiempo, y teniendo en cuenta la obligación de los contribuyentes de presentar declaraciones veraces, los contribuyentes están obligados, si así lo requiere la Administración Tributaria, en el contexto del procedimiento de fiscalización, que puede tener lugar en cualquier momento, dentro del plazo de prescripción (por lo general, cinco años), a presentar todos los documentos justificativos que confirman la validez de los datos presentados sobre sus ingresos en sus declaraciones de impuestos. Por lo tanto, en una primera fase, los contribuyentes tienen la obligación de demostrar la veracidad de la información declarada, mientras que la Administración Tributaria, en un primer momento, determinar el impuesto adeudado sobre la base de la declaración tributaria presentada. (Meussen et al., 2013, p. 119).

De lo expuesto, se advierte que a diferencia de los principios dispositivos, inquisitivo y facilidad probatoria, la autodeterminación se encuentra regulada en el Código Tributario, sin embargo, el legislador no ha establecido expresamente que constituya un principio que establezca regla de la carga de la prueba alguna, únicamente se dispone que los contribuyentes se encuentran obligados a presentarla y son sancionados con multa de no cumplir dicha obligación. 


\section{CAPÍTULO II: PROBLEMÁTICA DE LA CARGA DE LA PRUEBA EN EL PROCEDIMIENTO DE FISCALIZACIÓN}

A continuación revisaremos resoluciones del Tribunal Fiscal relacionadas a controversias respecto a la prueba en el procedimiento de fiscalización, a fin de determinar a quién le correspondía la carga de la prueba en dichos casos.

\subsection{RTF $N^{\circ}$ 18326-5-2012}

\section{- Punto Controvertido}

El contribuyente no presentó la declaración jurada determinativa del IGV del período abril de 2011 dentro del plazo establecido, por lo que la Administración le requirió información a fin de verificar si éste tenía la obligación de presentar dicha declaración, sin embargo, el contribuyente no presentó documentación sustentatoria alguna; y, en consecuencia, se emitió la multa por la infracción tipificada en el numeral 1 del artículo $176^{\circ}$ del Código Tributario.

A continuación, detallaremos como resolvió el Tribunal Fiscal el caso de análisis aplicando el principio inquisitivo, al considerar que la Administración Tributaria no había demostrado que el contribuyente reinició sus actividades en abril de 2011; sin embargo, en voto discrepante, un vocal sostiene que era el contribuyente quien tenía que probar que mantenía la suspensión de sus actividades en el referido período por haber declarado que reinició actividades en el mismo período y, además, porque éste se encontraba en mejor posición para demostrar aquello, aplicando de esta manera, los principios de autodeterminación y facilidad probatoria.

\section{- Principios aplicados por el TF}

Principio Inquisitivo

Que no obran en autos elementos que permitan concluir que el recurrente se encontraba afecto al Impuesto General a las Ventas en el mes de abril de 2011, período al que 
corresponde el valor impugnado, verificándose por el contrario que había comunicado la suspensión de sus actividades entre el 12 de enero y 3 de abril de 2011 (...), habiéndose limitado la Administración a señalar que toda vez que éste no cumplió con presentar lo solicitado mediante Requerimiento $\mathrm{N}^{\circ}(\ldots)$, no se ha podido verificar si realizó o no actividades comerciales durante el período materia de autos.

Que de lo expuesto se concluye que no se encuentra acreditado en autos que en el mes de abril de 2011 el recurrente se encontrara obligado a presentar la declaración jurada del Impuesto General a las Ventas, siendo que la Administración no ha acreditado lo contrario, en consecuencia, procede revocar la apelada y dejar sin efecto el valor impugnado. (RTF $\mathrm{N}^{\circ}$ 18326-5-2012)

Cabe anotar al respecto que el contribuyente comunicó el reinicio de sus actividades el 4 de abril de 2011, es decir, comunicó el reinició sus actividades en el mes por el cual se emitió la multa por no presentar la declaración jurada determinativa del IGV (abril de 2011), por lo que la Administración le requirió información a fin de verificar si le correspondía presentar la referida declaración; sin embargo y pese a que el contribuyente no presentó documentación alguna, el Tribunal Fiscal entiende que era la Administración Tributaria la obligada a acreditar que aquél estaba obligado a presentar la mencionada declaración.

\section{Principio de la autodeterminación y facilidad probatoria}

En voto discrepante el vocal Velásquez López Raygada señala lo siguiente:

(...) en casos como el de autos, en que un contribuyente del Impuesto General a las Ventas comunica la suspensión de sus actividades, y posteriormente su reinicio, tendrá la carga de la prueba a fin de acreditar que, en efecto, mantiene la primera de las condiciones señaladas, es decir aun tiene suspendidas sus actividades comerciales, no solo porque por propia declaración se tienen elementos suficientes para presumir que las reinicio, sino porque está en mejores condiciones que la Administración para entregar las pruebas respectivas que acreditasen que aun mantenía la referida suspensión.

Que al respecto cabe precisar que en la sentencia recaída en el Expediente $\mathrm{N}^{\circ}$ 1776-2004-AA/TC, el Tribunal Constitucional ha señalado que: "prima facie (...) la carga de probar corresponde a quien afirma hechos que configuran su pretensión, o a quien los contradice alegando nuevos hechos, según lo presenta el artículo $196^{\circ}$ del Código Procesal Civil. Frente a ello, la carga probatoria dinámica significa un apartamiento de los cánones regulares de la distribución de la carga de la prueba cuando 
ésta arroja consecuencias manifiestamente disvaliosas para el propósito del proceso o procedimiento, por lo que es necesario plantear nuevas reglas de reparto de la imposición probatoria haciendo recaer el onus probando sobre la parte que está en mejores condiciones profesionales, técnicas o fácticas para producir la prueba respectiva.

Que en ese sentido resulta pertinente precisar que en casos como el de autos, en que un contribuyente del Impuesto General a las Ventas comunica la suspensión de sus actividades, y posteriormente su reinicio, tendrá la carga de la prueba a fin de acreditar que, en efecto, mantiene la primera de las condiciones señaladas, es decir aun tiene suspendidas sus actividades comerciales, no solo porque por propia declaración se tienen elementos suficientes para presumir que las reinició, sino porque está en mejores condiciones que la Administración para entregar las pruebas respectivas que acreditasen que aun mantenía la referida suspensión. (RTF N 18326-5-2012)

Como se aprecia, con un criterio más acorde con lo declarado por el contribuyente respecto al reinicio de sus actividades en el mes por el cual se le multó por no presentar la declaración jurada y la facilidad probatoria del contribuyente, el vocal Velásquez López Raygada, consideró que éste tenía la carga de la prueba.

\section{- Análisis}

Como se aprecia, el órgano colegiado aplicó el principio inquisitivo para revocar la multa emitida por la Administración, señalando que ésta no demostró que el contribuyente se encontraba afecto al IGV en el período acotado, sin embargo, en voto discrepante un vocal alega la aplicación del principio de la carga dinámica de la prueba para sustentar que era el contribuyente el que debía demostrar que no había reiniciado operaciones como había declarado a la Administración.

\subsection{Sentencia del Expediente $\mathbf{N}^{\circ}$ 3864-2009-0}

\section{- Sumilla}

El contribuyente no canceló la contribución al SENATI de los períodos agosto de 2002 a octubre de 2003, por lo que la Administración emitió las resoluciones de determinación correspondientes al referido tributo y períodos. En instancia judicial, el contribuyente alegó que su empresa desarrolla varias actividades económicas, por lo que el promedio de trabajadores que tiene dedicados a la actividad industrial no superan 
la cantidad de veinte (20), por tanto, no estaba obligada al pago de la contribución al SENATI y que el Tribunal Fiscal no se había pronunciado respecto a dicho argumento.

Ahora bien, en el caso de autos, el órgano jurisdiccional consideró que el contribuyente tenía la carga de la prueba de sus afirmaciones, en aplicación de lo dispuesto en la LPAG, aplicando de este modo, el principio dispositivo.

\section{- Principio aplicado por la Sexta Sala Especializada en lo Contencioso} Administrativo con Subespecialidad en Temas Tributarios y Aduaneros de la

\section{Corte Superior de Justicia de Lima}

\section{Principio dispositivo}

"Respecto a que los trabajadores dedicados a la actividad industrial no superan los veinte (20), y que la resolución administrativa impugnada expedida por el Tribunal Fiscal no se ha pronunciado si la empresa cuenta en promedio con más de veinte trabajadores dedicados a la actividad industrial para que esté afecto al pago de la contribución al SENATI, es de señalar que la regla general establecida en el artículo $11^{\circ}$ de la Ley $\mathrm{N}^{\circ} 26272$, es que las empresas que se dedican a la actividad industrial comprendidas en la Categoría D de la "Clasificación Industrial Internacional Uniforme (CIIU) de todas las actividades económicas de las Naciones Unidas (Revisión 3)" están obligadas a contribuir con el SENATI, por lo que en caso que una empresa alegue estar exceptuada del pago de dicho tributo en virtud al artículo $13^{\circ}$ de la acotada ley, ésta debe de probar tal situación, correspondiéndole por ende la carga de la prueba y tener en cuenta lo prescrito en el numeral 162.2 del artículo $162^{\circ}$ de la Ley $\mathrm{N}^{\circ} 27444$, Ley del Procedimiento Administrativo General, que dispone: "Corresponde a los administrados aportar pruebas mediante la presentación de documentos e informes, proponer pericias, testimonios, inspecciones y demás diligencias permitidas, o aducir alegaciones". (Sentencia del Expediente №3864-2009-0).

Así las cosas, se advierte de la revisión del expediente principal y del administrativo, "que en éstos no obra documento alguno que acredite que la actora contaba con un promedio de veinte trabajadores (o menos) dedicados a la actividad industrial; es más, pese a que en el escrito de su demanda ofreció como medio probatorio el libro de planillas de su personal, no cumplió con presentar tal documento, a pesar de habérsele requerido (...); por el contrario, lo que si obra en los actuados administrativos es el documento denominado 
"Declaración para el registro del contribuyente" del 01 de diciembre de 2003, en el que la actora consignó que en los meses de agosto de 2002 a octubre 2003 contaba con un promedio de 69 trabajadores, lo que permite concluir que la demandante sí se encontraba obligada a contribuir con el SENATI en tal período (...)" (Sentencia del Expediente $\mathrm{N}^{\circ}$ 3864-2009-0).

Se advierte de lo expuesto, que el contribuyente pretendió no pagar la contribución al SENATI basado en una supuesta falta del cumplimiento del requisito referido a contar con más de veinte (20) trabajadores dedicados a la actividad industrial, señalando para tal efecto que el Tribunal Fiscal no se había pronunciado por dicho aspecto, sin embargo, el órgano jurisdiccional entiende que en tal caso la carga de la prueba le corresponde al contribuyente y que éste no había presentado la documentación sustentatoria correspondiente de acuerdo a lo establecido en la LPAG; y, por el contrario, presentó información que ratificaba que contaba con más de los referidos veinte (20) trabajadores. En tal sentido, consideramos que en este caso se aplicó el principio dispositivo pero desde la perspectiva de lo regulado en la LPAG.

\section{- Análisis}

Como se aprecia, contrario a otros casos, la sexta sala aplica lo establecido en la LPAG y no lo regulado en el Código Procesal Civil, para sostener que la carga de la prueba respecto a la excepción de no encontrarse gravada con la contribución al SENATI, le corresponde al contribuyente, por lo que si bien éste afirmó que no contaba con más de veinte (20) trabajadores no lo demostró, no correspondiendo amparar su demanda.

\subsection{Sentencia del Expediente $N^{\circ} 3490-2012$}

\section{- Sumilla}

El contribuyente efectuó una deducción a la renta imponible del ejercicio 2002 por concepto de la deducción del Resultado por Exposición a la Inflación (REI) de existencias del 2001, señalando (en respuesta al requerimiento específico de sustentación) que el REI negativo agregado a la renta neta del ejercicio 2001, constituye una partida temporal que se incorpora al costo del activo, cuya recuperación se producirá al momento de su enajenación como componente del costo tributario en el 
ejercicio en que se produzca la baja contable y que la Administración tuvo a su disposición la información que permitía corroborar que la enajenación se produjo en el ejercicio 2002, tales como, libros, registros y otros documentos (presentados en atención al requerimiento general emitido por la Administración).

La Administración por su parte sostiene que el argumento del contribuyente pretende revertir su carga de probar la afirmación de que la enajenación de existencias del ejercicio 2001 se produjo en el ejercicio 2002, por lo reparó la citada deducción.

A continuación, detallaremos como resolvió sexta sala el caso de autos, considerando que la Administración Tributaria tenía el deber de probar en el procedimiento fiscalización, por lo que debió evaluar de forma idónea los medios probatorios presentados por éste y formularle un requerimiento específico a fin de que sustente sus afirmaciones, si los indicados medios probatorios no le generaban convicción, aplicando de esta manera, el principio inquisitivo.

\section{- Principio aplicado por la Sexta Sala Especializada en lo Contencioso} Administrativo con Subespecialidad en Temas Tributarios y Aduaneros de la Corte Superior de Justicia de Lima

\section{Principio Inquisitivo}

(...) citándose así a la jurista brasileña Fabiana del Padre Tomé para quien (...) no tiene la autoridad administrativa mera carga de probar el hecho jurídico o el ilícito tributario que da soporte a sus actos, sino verdadero deber (...). Que, aunado a las ideas vertidas, no menos importante resulta importante destacar igualmente, en el análisis del caso concreto, la plena vigencia del principio de verdad material, íntimamente ligado al interés público que subyace en toda discusión tributaria, consagrado en el artículo IV, inciso 1.11, del Título Preliminar de la Ley número 27444, en cuya virtud, en el procedimiento, la autoridad administrativa competente deberá verificar plenamente los hechos que sirven de motivo a sus decisiones, para lo cual deberá adoptar todas las medidas probatorias necesarias autorizadas por la ley, (...) no cabe duda de que la tesis de defensa esgrimida por la Procuraduría Pública de la SUNAT y que sirve de basamento para el propio reparo en examen, así como para la decisión adoptada por el Tribunal Fiscal, carece de rigor de un adecuado sustento, en tanto importa y revela un proceder de la Administración Tributaria, al interior del procedimiento de fiscalización, no acorde con el "deber de probar" que le atañe, en cuya virtud, en principio, debió 
valorar idóneamente los medios probatorios aportados por el contribuyente, y aun en el supuesto de considerar que esta última no presentó la documentación contable a efectos de sustentar sus afirmaciones, pudo y debió formularle el requerimiento pertinente orientado a la exhibición o presentación de la misma (...). (Sentencia del Expediente $\left.\mathrm{N}^{\circ} 3490-2012\right)$.

Cabe anotar que en el caso concreto la Administración solicitó que se declarara nula la sentencia de primera instancia debido a que había declarado la nulidad parcial de la resolución del Tribunal Fiscal considerando que mediante el requerimiento de sustentación emitido por la Administración se solicitó de forma general la documentación original que sustentaba la deducción del REI de existencias del ejercicio 2001 pese a que mediante dicho requerimiento se exigió específicamente que la citada empresa sustente con documentación dicha deducción y la no enumeración de los documentos que se debían presentar respondió a la protección del derecho de defensa del contribuyente, otorgándosele libertad de probanza para no limitar los documentos que creyera pertinente presentar.

Ahora bien, cabe anotar que de acuerdo a la sentencia analizada, el contribuyente presentó documentación contable general y en atención al requerimiento de sustentación sobre el REI únicamente señaló que la Administración ya contaba con dicha documentación sin esbozar detallada y específicamente cuál era esa información y de qué manera la misma sustentaba que la enajenación de existencias del ejercicio 2001 se produjo en el ejercicio 2002, hecho que la Administración consideró como una evasión de parte del contribuyente de su carga de probar la mencionada enajenación.

No obstante, sin mayor análisis sobre los documentos presentados por el contribuyente en atención al requerimiento general y sin evaluar su conexión con el reparo en cuestión, la sentencia de segunda instancia, concluyó que la Administración era la que tenía el deber de probar $\mathrm{y}$, de ser el caso, formularle al contribuyente un nuevo requerimiento de sustentación.

\section{- Análisis}

Como se aprecia, el órgano jurisdiccional expone como sustento de su fallo el principio inquisitivo, señalando que si bien el contribuyente había respondido al requerimiento de sustentación del REI señalando que la Administración tuvo a su disposición la 
información que permitía corroborar que la enajenación de las existencias al cierre del ejercicio 2001, se produjo en el ejercicio 2002 (sin especificar mayor detalle), aquélla tenía el deber de probar la verdad material de los hechos.

\subsection{Sentencia del Expediente $N^{\circ}$ 2000-2011-0}

\section{- Sumilla}

El contribuyente efectuó compras a diversos proveedores y consideró como crédito fiscal el IGV de las mismas, sin embargo, la Administración reparó reparo dicho crédito fiscal por considerar que correspondían a operaciones no reales.

En el presente caso, la sala aplicó el principio dispositivo y sostuvo que la carga de la prueba respecto de las operaciones no reales le correspondía tanto a la Administración Tributaria como al contribuyente.

- Principio aplicado por la Sexta Sala Especializada en lo Contencioso Administrativo con Subespecialidad en Temas Tributarios y Aduaneros de la Corte Superior de Justicia de Lima

\section{Principio Dispositivo}

(...) para determinar si una operación es no real o no fehaciente la Administración Tributaria debe valorar los documentos presentados por el contribuyente en la etapa de fiscalización así como realizar cruces de información que le permitan corroborar sus presunciones de falsedad o irrealidad de la operación (...).

Asimismo, los medios probatorios que presente el contribuyente deben estar destinados a sustentar la fehaciencia de la operación, pues no basta tan solo alegar que el comprobante de pago cumple con todos los requisitos legales, sino se debe recurrir a otros medios de prueba que cumplan con dicho fin, tales como el cargo de recepción de los bienes, la guía de remisión, ingreso al almacén contrato de servicios, cartas, mails, informes de servicio contratado, etc. Por lo antes señalado la carga de la prueba de la fehaciencia de las operaciones recae tanto en la SUNAT como en el contribuyente. (Sentencia del Expediente $N^{\circ}$ 2000-2011-0).

Cabe anotar que sobre la observación a la necesidad de adquisición de los productos, el órgano colegiado indicó que el contribuyente se limitó a señalar de forma general que 
los productos detallados en las facturas observadas eran necesarios para su actividad comercial, sin sustentar con la documentación pertinente que efectivamente así lo eran, máxime si del cruce de información con las empresas proveedoras se llegó a la conclusión que las mismas tampoco sustentaron haber realizado las operaciones de venta consignadas en las aludidas facturas.

Además, para sustentar el reparo en cuestión, el contribuyente presentó guías de remisión que el colegiado consideró que no cumplían con las formalidades del Reglamento de Comprobantes de Pago, por lo que no sustentaban el traslado de mercadería y declaraciones de los representantes legales de los proveedores inconsistentes con lo indicado por el contribuyente.

Asimismo, el órgano colegiado indicó que el contribuyente no había sustentado la observación al origen del dinero para las adquisiciones de cheques de gerencia y sobre las personas que lo recibieron, toda vez que solo indicó que el dinero correspondía a utilidades de la empresa sin sustentar contable ni financieramente su origen, más aún si en el Libro Caja no se registraron las operaciones en forma detallada sino general por todas las operaciones mensuales y, en cuanto a las personas que recibieron los cheques de gerencia, el contribuyente en sede administrativa señaló que todos los pagos y depósitos efectuados fueron entregados a los propios representantes legales de los proveedores, mientras que en sede judicial, alega que los cheques fueron recepcionados por el administrador y asesor de los mismos.

En tal sentido y en aplicación del principio dispositivo antes descrito, el colegiado consideró que el contribuyente no logró desvirtuar las observaciones realizadas por la Administración al crédito fiscal por determinarse que correspondían a operaciones no reales.

\section{- Análisis}

Como se aprecia, el órgano jurisdiccional expone como sustento de su fallo el principio dispositivo, señalando que el contribuyente no sustentó las compras observadas por la Administración Tributaria, toda vez que sólo se limitó a esgrimir argumentos referidos a la necesidad de dichas compras sin presentar la documentación sustentatoria que acredite la fehaciencia de las mismas. 


\subsection{Sentencia Tribunal Constitucional Expediente $\mathbf{N}^{\circ}$ 02647-2011-PA/TC}

\section{- Sumilla}

El contribuyente celebró un contrato de joint venture con dos empresas A y B, el cual establecía que la contabilidad recaería sobre B, sin embargo, el contribuyente dedujo dentro de su base imponible del Impuesto a la Renta neta del ejercicio 2000, las utilidades correspondientes a las operaciones de los ejercicios 1997, 1998 y 1999, pertenecientes a la empresa A; por lo que la Administración consideró que no correspondía que el contribuyente efectuara la provisión por dicho concepto a fin de reducir la base imponible del ejercicio 2000, sino que debió efectuar la provisión correspondiente a cada uno de los ejercicios fiscales 1997, 1998 y 1999, en aplicación de lo establecido en el artículo $29^{\circ}$ de la Ley del Impuesto a la Renta.

En sede constitucional, el contribuyente alega que la sentencia de vista no se encuentra debidamente motivada y que el principio de veracidad se interpretó erróneamente, toda vez que se solicita que aquél pruebe que las declaraciones y los documentos presentados corresponden a la verdad de los hechos, siendo que, según este principio, la propia Administración está obligada a la carga de la prueba.

A continuación, detallamos cómo interpretó el órgano constitucional el referido principio, así como aplicó el principio dispositivo para resolver el caso materia de análisis.

\section{- Principio aplicable por el Tribunal Constitucional}

\section{Principio dispositivo}

(...) en cuanto a la presunción de veracidad que se reclama, la resolución objetada se sustenta el requerimiento solicitado señalando que la veracidad de los documentos presentados no es absoluta, tal como lo indica el numeral 1.7 del artículo IV del Título Preliminar de la Ley 27444, por lo que se pidió documentación sustentatoria a fin de acreditar una correcta tributación; sin embargo, la recurrente presentó su descargo omitiendo adjuntar el sustento probatorio, lo cual determinó la sanción impuesta, no siendo obligación de la Administración procurar de oficio la documentación solicitada y no adjuntada diligentemente por las partes. (Sentencia Tribunal Constitucional Expediente $\mathrm{N}^{\circ}$ 02647-2011-PA/TC). 
Como se aprecia, el órgano constitucional si bien no indica expresamente que la carga de la prueba le corresponde al contribuyente, del texto indicado, deja claramente establecido que el principio de veracidad no exime al contribuyente de sustentar sus descargos con la documentación correspondiente, toda vez que dicho principio no es absoluto y menos aún obliga a la Administración a diligenciar u obtener dicha documentación. Así, aplica el principio dispositivo para desconocer lo solicitado por el contribuyente en relación a la deducción de utilidades correspondientes a los ejercicios 1997, 1998 у 1999.

\section{- Análisis}

Como se aprecia, a través de una interpretación del principio de presunción de veracidad, el órgano constitucional colige que la carga de la prueba respecto de sus descargos le corresponde al contribuyente, por lo que aplica el principio dispositivo para resolver el caso analizado.

\subsection{RTF $\mathrm{N}^{\circ}$ 18397-10-2013}

\section{- Punto Controvertido}

El contribuyente efectúo deducciones a la renta neta imponible del ejercicio 2002 por concepto de Paridad de Flete (Freight Parity) vinculada a la venta de cátodos de cobre del Proyecto “Óxidos”, por el monto de US\$1’172,445.58 al considerar que si bien en los contratos exhibidos acordó inicialmente que la entrega de material en cuestión seria a precio CIF Rotterdam, Holanda, el mismo fue exportado bajo el Incoterm FOB Matarani, Perú. Al ser requerido por la Administración, esta determine que no se acreditó con la documentación sustentatoria que el flete deducido corresponda efectivamente al costo del traslado del mineral o que el mismo provenga del procedimiento de Paridad de Flete a que se refiere el contrato exhibido.

A continuación, detallaremos como resolvió el Tribunal Fiscal el caso de análisis aplicando el principio inquisitivo, al considerar que en los procedimientos de fiscalización la carga de la prueba se rige por el principio de impulso de oficio, y en ese sentido, como regla general, corresponderá a la Administración desvirtuar los precios, descuentos y deducciones acordados contractualmente, salvo disposición expresa que 
revierta la carga de la prueba a los propios administrados; razona la sala que incluso invocando la teoría de la carga probatoria dinámica igualmente la carga de la prueba recae en la Administración por estar en mejor posición para ello, en atención a las amplias atribuciones que le ha conferido el artículo $62^{\circ}$ del Código Tributario para el ejercicio de su facultad fiscalizadora, aplicando de esta manera, el principio de facilidad probatoria.

Finalmente la sala confirma su posición aplicando el principio dispositivo, al señalar que el artículo $196^{\circ}$ del Código Procesal Civil, según el cual la carga de la prueba corresponde a quien afirma un hecho, en el presente caso correspondía a la Administración, que controvierte el valor asignado en las operaciones anotadas, desvirtuar dicho valor mediante los medios probatorios correspondientes.

\section{- Principios aplicados por el Tribunal Fiscal}

\section{Principio Inquisitivo}

Que es preciso mencionar que de acuerdo con el artículo $162^{\circ}$ de la Ley del Procedimiento Administrativo General, Ley $\mathrm{N}^{\circ}$ 27444, aplicable supletoriamente conforme a lo previsto por la Norma IX del Título Preliminar del Código Tributario, la carga de la Prueba se rige por el principio de impulso de oficio establecido en dicha ley.

Que con relación a dicha norma Morón Urbina señala que "la Administración actúa permanentemente en búsqueda de la verdad material en todos sus órdenes. Por eso, sobre ella recae el deber de practicar todas las diligencias probatorias que produzcan conocimiento y convencimiento de certeza, (...)", y en ese sentido, "la aplicación de la oficialidad al aspecto probatorio impone a la Administración: la obligación de verificar y probar los hechos que se imputan o que han de servir de base a la resolución del procedimiento", de modo que por lo general, los administrados no tienen el deber de probar, salvo en procedimientos especiales donde las normas legales pueden imponerles esa obligación (...). Que de lo antes expuesto se concluye que en los procedimientos de fiscalización la carga de la prueba rige por el principio de impulso de oficio y, en este sentido, como regla general, corresponderá a la Administración desvirtuar los precios, descuentos y deducciones acordados contractualmente, salvo disposición legal expresa que revierta la carga de la prueba a los propios contribuyentes. (RTF $\mathrm{N}^{\circ}$ 18397-102013). 
Cabe anotar que la Administración no cuestiona que las operaciones materia de reparo se hubiesen efectuado en términos FOB Matarani, Perú y no en términos CIF Rotterdam como inicialmente se tenía pactado sino el hecho que la recurrente no hubiese sustentado documentariamente las diferencias entre los costos de embarque al puerto de Rotterdam y los términos de entrega efectivamente producidos.

En aplicación del principio inquisitivo, el Tribunal concluye que como regla general le corresponderá a la Administración desvirtuar los precios, descuentos y deducciones acordados contractualmente.

\section{Principio de facilidad probatoria}

Que cabe agregar que incluso invocando la teoría de la carga probatoria dinámica, respecto de la cual se ha pronunciado el Tribunal Constitucional en reiteradas resoluciones como la recaída en el Expediente $\mathrm{N}^{\circ}$ 1776-2004-AA/TC -que se basa en los principios procesales de solidaridad y colaboración, y que flexibiliza la regla de la carga de la prueba desplazándola, según fueran las circunstancias del caso, en aquél que está en mejores posiciones profesionales, técnicas y fácticas para producir la prueba, lo que resulte consistente con el principio de verdad material-, la carga de la prueba para desvirtuar los precios, descuentos y deducciones acordados por las partes recae igualmente sobre la Administración Tributaria por estar en mejor posición para ello, en atención a las amplias prerrogativas que le ha atribuido el artículo $62^{\circ}$ del Código Tributario para el ejercicio de su facultad fiscalizadora. (RTF N 18397-10-2013).

En este caso, observamos que el Tribunal recurre al principio de facilidad probatoria para confirmar su posición respecto a que sobre la Administración recae la carga de la prueba, porque es ella quien está en mejor posición de probar en merito a las amplias atribuciones que se le ha conferido para el ejercicio de su facultad discrecional.

\section{Principio dispositivo}

Que sobre el particular, estando a las normas legales glosadas y a lo señalado además en el artículo $196^{\circ}$ del Código Procesal Civil, según el cual la carga de la prueba corresponde a quien afirma un hecho -de aplicación supletoria en material tributaria de virtud de lo dispuesto en la Norma IX del Título Preliminar del Código Tributario-, en el presente caso correspondía a la Administración, que controvierte el valor asignado en 
las operaciones antes anotadas, desvirtuar dicho valor mediante los medios probatorios correspondientes.

Que en efecto, dado que es la Administración quien cuestiona los importes de las deducciones bajo análisis, le correspondía a ésta la carga de la prueba a efecto de sustentar documentariamente que los valores utilizados por el contribuyente, pactados contractualmente, excedían lo dispuesto en el artículo $64^{\circ}$ de la Ley del Impuesto a la Renta y el artículo $37^{\circ}$ de su Reglamento antes glosados, lo que no hizo". (RTF N ${ }^{\circ}$ 18397-10-2013).

Como se aprecia, el Tribunal razona que al ser la Administración la que controvierte la deducción declarada por el contribuyente, en merito al principio dispositivo, es ella en quien recae la carga de la prueba.

\section{- Análisis}

Como se aprecia, para el Tribunal en la aplicación indistinta del principio inquisitivo, de facilidad probatoria y dispositivo, en cualquiera de ellas, era la Administración la llamada a soportar la carga de la prueba. Por lo que al no haber sustentado su posición resultaba procedente la deducción a que se refiere el concepto "Freight Parity", por lo que levanta el reparo y revoca la resolución apelada en dicho extremo.

\subsection{RTF $N^{\circ}$ 07578-8-2014}

\section{- Sumilla}

La Administración reparó gastos por servicios profesionales relacionados a la determinación del Impuesto a la Renta del ejercicio 2002, al no acreditar el contribuyente fehacientemente la efectiva prestación de los servicios profesionales por parte de su proveedor Deloitte \& Touche S.R.L.

A continuación, detallaremos como resolvió la sala el caso, considerando que era el contribuyente quien tenía la carga de la prueba de la realidad y la fehaciencia de sus operaciones, en base al principio dispositivo. Si bien el contribuyente alega que la carga de la prueba era de la Administración el Tribunal señala que ello debe efectuarse sobre la base de elementos de prueba mínimos que el contribuyente debe presentar, hecho que no sucedió en el caso materia de análisis. 
Finalmente, la sala confirma su posición aplicando el principio de facilidad probatoria y de autodeterminación, señalando que en ambos casos le correspondía al contribuyente probar la fehaciencia de sus operaciones, dado que se encontraba en mejor posición para ello y por corresponder a operaciones que sustentan los gastos y crédito fiscal declarados por el contribuyente.

\section{- Principios aplicados por el Tribunal Fiscal}

\section{Principio dispositivo, inquisitivo y deberes de colaboración}

(...), si bien es cierto que es aplicable a la Administración el principio de verdad material, según el cual, la autoridad administrativa competente deberá verificar plenamente los hechos que sirven de motivo de sus decisiones, para lo cual deberá adoptar las medidas probatorias necesarias autorizadas por ley, aun cuando no hayan sido propuestas por los administrados, de modo que la Administración debe realizar las actuaciones necesarias a efectos de verificar la realidad de la operación, también lo es que ello puede efectuarse sobre la base de información que mínimamente deben $\operatorname{presentar}(\ldots)$.

Que en la misma medida, carece de sustento lo alegado por la recurrente respecto a que se debió actuar pruebas de oficio en virtud del principio de impulso de oficio, habida cuenta, que por los mismos fundamentos antes citados, la recurrente no cumplió con proporcionar los elementos de prueba mínimos.

Que la recurrente también alega que correspondía a la Administración desvirtuar lo manifestado por las partes en la celebración del contrato cuya existencia quedó demostrada por la existencia de facturas y demás documentación proporcionada. No obstante, la recurrente en la fiscalización solo proporcionó las facturas y la acreditación de su anotación contable y no presentó la demás documentación que pudiera sustentar la prestación del servicio, siendo ella la que tenia la carga de la prueba de la realidad y fehaciencia de sus operaciones. (RTF $N^{\circ} 07578-8-2014$ )

Como se aprecia en la resolución analizada, el contribuyente demanda la aplicación del principio inquisitivo, y por ende, que la carga de la prueba sea de cargo de la Administración, sin embargo el Tribunal aclara que ello debe efectuarse sobre la base de elementos de prueba mínimos que el contribuyente debe presentar, aludiendo con ello a los deberes de colaboración. De otro lado, el Tribunal precisa que era el 
contribuyente quien tenía la carga de la prueba de la realidad y fehaciencia de sus operaciones, aplicando con ello el principio dispositivo.

\section{Principio de facilidad probatoria}

Que tal como ella misma lo refiere (el contribuyente), este Tribunal en la Resolución $\mathrm{N}^{\circ}$ 18397-10-2013, ha hecho referencia a la teoría de la carga probatoria dinámica, respecto de la cual se ha pronunciado el Tribunal Constitucional en reiteradas resoluciones como la recaída en el Expediente $\mathrm{N}^{\circ}$ 1776-2017-AA/TC -que se basa en los principios procesales de solidaridad y de colaboración y que flexibiliza la regla de la carga de prueba desplazándola, según fueran las circunstancias del caso, en aquél que está en mejores posiciones profesionales, técnicas y fácticas para producir la prueba, lo que resulta consistente con el principio de verdad material-, sin embargo, a diferencia del caso que motivó la emisión de la citada resolución, en este era la recurrente la que estaba en mejor posición para acreditar la fehaciencia de la operación dado que las pruebas correspondientes están en el ámbito de las partes que, según ella misma afirma, participaron en el contrato y en la prestación de servicios objeto de las facturas, lo que no hizo durante la fiscalización, pese a que en atención a su facultad de fiscalización y conforme con el artículo $62^{\circ}$ del Código Tributario, la Administración le solicitó que presentara tales pruebas ( $\left.\mathrm{RTF} \mathrm{N}^{\circ} 07578-8-2014\right)$.

En este caso, el Tribunal recurre al principio de facilidad probatoria para confirmar su posición respecto a que en el contribuyente recae la carga de la prueba, porque es ella quien está en mejor posición de probar dado que las pruebas están en el ámbito de las partes que participaron en el contrato y la prestación de los servicios material de controversia.

\section{Principio de autodeterminación y presunción de veracidad}

Que con relación al principio de presunción de veracidad, cabe mencionar que tal como se establece en el numeral 1.7 del artículo IV del Título Preliminar de la Ley del Procedimiento Administrativo General, se presume que los documentos y declaraciones formulados por los administrados en la forma prescrita por la ley responden a la verdad de los hechos que ellos afirman, pero admitiéndose prueba en contrario, siendo que en virtud de esto último y a que concordantemente indica el Código Tributario, las declaraciones de los deudores tributarios pueden ser sujetas de verificación o 
fiscalización por parte de la Administración, y concretamente se puede solicitar la acreditación de la fehaciencia de las operaciones que sustentan los gastos y crédito fiscal declarados (...). (RTF $\left.N^{\circ} 07578-8-2014\right)$.

El Tribunal señala que si bien se presume la veracidad de las declaraciones presentadas por el contribuyente, esta presunción admite prueba en contrario, por lo que la Administración en el ejercicio de sus facultades de fiscalización puede verificar y solicitar la acreditación de las operaciones declaradas por el contribuyente.

\section{- Análisis}

Como se aprecia, el Tribunal concluye que la carga de la prueba de la realidad y fehaciencia de las operaciones declaradas recae en el contribuyente (principio de autodeterminación y dispositivo). Asimismo, que dado que las pruebas están en el ámbito de las partes, era el contribuyente la que estaba en mejor posición para acreditar la fehaciencia de la operación (principio de facilidad probatoria). Y que si bien es cierto que es aplicable a la Administración el principio de verdad material e impulso de oficio, también lo es que ello puede efectuarse sobre la base de la información que los contribuyentes mínimamente deben presentar (principio inquisitivo y deberes de colaboración).

\subsection{RTF $N^{\circ}$ 05991-5-2014}

\section{- Sumilla}

La Administración formuló reparos a la renta neta del Impuesto a la Renta del ejercicio 2000 por subvaluación en la enajenación de los bienes Motocicleta Suzuki DR-125SJ y Motocicleta FB-100G por no haber sido sustentados por el contribuyente.

A continuación, detallaremos como resolvió la sala el caso, considerando que en base a los principio de autodeterminación, facilidad probatoria y dispositivo era el contribuyente quien tenía la carga de la prueba del valor de venta de sus operaciones.

\section{- Principios aplicados por el Tribunal Fiscal}

Principio de autodeterminación y deberes de colaboración 
Según ha señalado este Tribunal en la Resolución $N^{\circ}$ 05578-5-2014, del texto de la norma en cuestión queda claro que esta impone una obligación a los contribuyentes, quienes son los llamados por ley a determinar en un primer momento la obligación tributaria (...).

(...) la Administración estará facultada a solicitar a los contribuyentes que acrediten que el valor usado en la totalidad de sus operaciones o en algunas de ellas identificadas específicamente, se ajustan al valor de mercado, pudiendo hacer una genérica solicitud, limitada temporalmente por uno o más periodos tributarios, sin que necesariamente tenga que oponer un valor de mercado, situación en la que el contribuyente tendrá que acreditar el tipo de operaciones que realice y las condiciones especificas de cada una, para así demostrar que en efecto se ajustan a lo dispuesto en la citada norma (...). (RTF $\mathrm{N}^{\circ}$ 05991-5-2014)

Como se aprecia en el Tribunal concluye que el contribuyente es el obligado en un primer momento a determinar su obligación tributaria (principio de autodeterminación) y para ello deberá acreditar el tipo de operaciones que realiza (deberes de colaboración) y demostrar que los referidos valores se ajustan al valor de mercado.

\section{Principio de facilidad probatoria}

Que asimismo se ha señalado en la citada resolución que habida cuenta que no solo existe claramente una asimetría en la información sobre las operaciones realizadas por los contribuyentes, donde estos son los que controlan toda la relacionada a las variables que han influido en el valor al que transaron cada una de sus operaciones, sino que sobre todo porque son estos los que definen qué variables especificas y en que medida influyen en el valor de sus existencias, recaerá exclusivamente en ellos proporcionar a la Administración, cuando esto le sea requerido, la documentación que acredite todas y cada una de esas variables (...). (RTF $\mathrm{N}^{\circ}$ 05991-5-2014)

En este caso, el Tribunal alude al principio de facilidad probatoria para señalar que es el contribuyente quien se encuentra en mejor acceso a la prueba de las operaciones realizadas.

\section{Principio dispositivo}

Que en cuanto lo alegado por la recurrente en el sentido que le corresponde a la Administración acreditar que la mercadería fue subvaluada, cabe señalar que la carga 
de la prueba recae en los contribuyentes, quienes tienen que acreditar las circunstancias, elementos y factores que afirman se habían producido y por las que se habrían utilizado determinado valor de venta en las operaciones (...). (RTF $\mathrm{N}^{\circ}$ 05991-5-2014)

Contrario a lo alegado por el contribuyente, el Tribunal señala que es ella la que afirma los hechos que se habrían producido que determinaron el valor de sus operaciones declaradas, por tanto sobre el contribuyente recae la carga de la prueba de los hechos que alega.

\section{- Análisis}

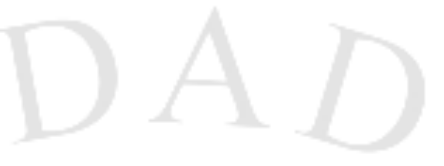

Como se aprecia, el Tribunal concluye que la carga de la prueba de los valores declarados en sus operaciones se ajusten al valor de mercado recae en el contribuyente (principio de autodeterminación). Señala además que en este caso son ellos quienes controlan toda la información relacionada a las variables que han influido en la determinación del valor de venta de sus operaciones (principio de facilidad probatoria) y finalmente es dicha parte la que afirma la ocurrencia de los hechos (principio dispositivo) por ende la obligada a probar.

\subsection{RTF $N^{\circ}$ 02206-2-2015}

\section{- Sumilla}

La Administración formuló reparos al crédito fiscal del Impuesto General a las Ventas de los meses de noviembre y diciembre de 2004 por operaciones no reales por no haber el contribuyente presentado las guías de remisión que acrediten la recepción de los bienes adquiridos de su proveedor, tampoco obtuvo documentación fehaciente del cruce de información efectuado y se verificó que éste no contaba con los elementos idóneos para realizar la venta de los bienes observados.

A continuación, detallaremos como resolvió la sala el caso, considerando el principio dispositivo, inquisitivo y la importancia de los deberes de colaboración.

\section{- Principios aplicados por el Tribunal Fiscal}




\section{Principio dispositivo, inquisitivo y deberes de colaboración}

Resulta claro que este Tribunal, a efectos de analizar la realidad o no de una o varias operaciones de compra, ha fijado como criterio general que la carga de la prueba respecto de su existencia y/o realidad, recae primordialmente en el contribuyente quien alega su existencia, pudiendo la Administración, mediante cruces de información, entre otros, aportar elementos de prueba que considerase necesarios con la finalidad de acreditar la inexistencia de aquellas, por lo que si un contribuyente no aporta elementos concluyentes, podría no acreditarse la realidad de sus operaciones aun cuando no llegase a efectuar con terceros cruce de información alguno. (RTF $N^{\circ}$ 02206-2-2015)

Como se aprecia el Tribunal reitera que en los casos de fehaciencia y/o realidad de operaciones, como criterio general, la carga de la prueba recae en el contribuyente quien alega su existencia (principio dispositivo), dejando a discrecionalidad de la Administración los cruces de información y otros que aporten pruebas de la inexistencia de las operaciones (principio inquisitivo) por lo que la no aportación de pruebas por parte del contribuyente (deberes de colaboración) podría devenir en lesivo para sus intereses.

\section{- Análisis}

El Tribunal resuelve el caso mediante la aplicación del principio dispositivo, al concluir que es el contribuyente sobre quien recae la carga de la prueba al ser ella quien alega la existencia de las operaciones materia de controversia. Añade además, que al no haber alcanzado, el contribuyente, con mantener un nivel de prueba mínimo indispensable, quedaba a criterio discrecional de la Administración los cruces de información y otros que aporten pruebas de la inexistencia de las operaciones (principio inquisitivo).

\subsection{0. $\quad$ RTF $N^{\circ}$ 01889-8-2015}

\section{- Sumilla}

El contribuyente realizó la deducción de gastos por pérdida extraordinaria en la determinación de la renta neta del Impuesto a la Renta del ejercicio 2007, alegando, entre otros, que con las denuncias presentadas la carga de la prueba se revierte sobre la Administración en aquellos casos en los que existe duda sobre los hechos delictivos ocurridos en agravio de los contribuyentes. 
De otro lado, la Administración sostiene que le contribuyente no cumplió con probar judicialmente los hechos delictuosos o que resultara inútil ejercitar la acción judicial correspondiente.

\section{- Principios aplicados por el Tribunal Fiscal}

\section{La carga de la prueba según disposición legal y el principio inquisitivo}

Que la recurrente argumenta que, dadas las facultades previstas por el Código Tributario y el Reglamento de Fiscalización a favor de la Administración, es está la que tiene la carga de la prueba con respecto a cualquier duda que pueda surgir con motivo de hechos delictuosos ocurridos en agravio de los contribuyentes (...). Asimismo, sostiene que en virtud del inciso d) del artículo $13^{\circ}$ del Reglamento de Fiscalización y el numeral 11 del artículo $62^{\circ}$ del Código Tributario, la Administración puede suspender el procedimiento de fiscalización y, a partir de cruces de información, determinar si los hechos descritos en las denuncias policiales presentadas son conformes o no.

Que de lo expuesto se desprende que la inversión de la carga de la prueba a que alude la recurrente se sustenta en las facultades conferidas por el ordenamiento jurídico a favor de la Administración para llevar a cabo, entre otros, el procedimiento de fiscalización, y es en base a este argumento que la recurrente pretende omitir el sustento de la deducción materia de reparo.

Que en cuanto a lo señalado cabe indicar que de la lectura del inciso d) del artículo $37^{\circ}$ de la Ley del Impuesto a la Renta, se desprende que son los contribuyentes quienes deben acreditar, judicialmente el hecho delictuoso, o acreditar que es inútil ejercitar la acción judicial correspondiente. (RTF $\mathrm{N}^{\circ}$ 01889-8-2015)

En este caso, el Tribunal precisa que la norma analizada es la que ha atribuido la distribución de la carga de la prueba, por ello los en los casos de gastos por pérdida extraordinaria es el contribuyente sobre quien recae probar judicialmente el hecho delictuoso o en su caso acreditar que es inútil ejercer la acción judicial correspondiente. Por lo cual los contribuyentes no se pueden amparar en el principio inquisitivo para pretender omitir el sustento de la operación material de reparo. 


\section{Principio de facilidad probatoria}

Que a mayor abundamiento, este Tribunal en la resolución $\mathrm{N}^{\circ}$ 18397-10-2013, ha hecho referencia a la teoría de la carga probatoria dinámica, respecto de la cual se ha pronunciado el tribunal Constitucional en reiteradas resoluciones, como la recaída en el Expediente $\mathrm{N}^{\circ}$ 1776-2007-AA/TC -que se basa en los principios procesales de solidaridad y de colaboración y que flexibiliza la regla de la carga de la prueba desplazándola, según fueran las circunstancias del caso, en aquél que está en mejores posiciones profesionales, técnicas y fácticas para producir la prueba, lo que resulta consistente con el principio de verdad material-.

Que considerando lo expuesto, la recurrente es la que estaba en mejor posición para probar el hecho delictuoso o que resultaba inútil ejercitar la acción judicial correspondiente, más aun si ella era la denunciante y parte agraviada de los presuntos delitos de "robo", siendo la Administración parte ajena a las acciones seguidas por la recurrente. (RTF $\mathrm{N}^{\circ}$ 01889-8-2015)

Como se aprecia el Tribunal aplica el principio de facilidad probatoria para ratificar su posición, es decir que la carga de la prueba en el caso materia de análisis recae en el contribuyente, por ser ella quien está en mejor posición de probar los hechos que alega.

\section{- Análisis}

El Tribunal resuelve el caso de la deducción de pérdidas extraordinarias es la que ha establecido sobre la base que norma que la regula ha atribuido la carga de la prueba al contribuyente. De otro lado señala, que no se puede exigir la aplicación del principio inquisitivo como sustento para omitir cumplir con el sustento de la deducción que le ha sido atribuida por ley.

Finalmente, el Tribunal concluye que aun aplicando el principio de facilidad probatoria, es el contribuyente, denunciante y parte agraviada, quien está en mejor posición de probar los hechos que se alegan. 


\section{CAPÍTULO III: PROBLEMÁTICA DE LA CARGA DE LA PRUEBA EN EL PROCEDIMIENTO FISCALIZACIÓN}

\subsection{Problemática y necesidad de regulación de las reglas de la carga de la prueba}

Nuestro código no establece reglas sobre la carga de la prueba, por lo que ante la falta de éstas corresponde aplicar la Norma IX del Título Preliminar del Código Tributario, la cual establece que en lo no previsto por dicho código o en otras normas tributarias, podrán aplicarse normas distintas, siempre que no se les opongan, ni las desnaturalicen. Ahora bien ¿Cuáles son estas normas? de las cuales extraeremos las reglas de la carga de la prueba aplicables al procedimiento de fiscalización.

En el Capítulo II del presente trabajo, hemos analizado las resoluciones emitidas por el Tribunal Fiscal, el Poder Judicial y el Tribunal Constitucional, en las cuales, éstos, en merito a la mencionada Norma IX han basado su razonamiento, en distintas normas supletorias, en algunas ocasiones han señalado que de acuerdo al artículo $196^{\circ}$ del Código Procesal Civil, la carga de la prueba corresponde a quien afirma hechos que configuran su pretensión, o a quien los contradice alegando nuevos hechos (principio dispositivo). En otras resoluciones, han sostenido que de acuerdo al artículo $162^{\circ}$ de la Ley del Procedimiento Administrativo General, Ley N ${ }^{\circ} 274444$, la carga de la prueba se rige por el principio de impulso de oficio establecido en dicha ley (principio inquisitivo).

Además de ello, en algunas resoluciones, han introducido la Teoría de las Cargas Probatorias Dinámicas (principio de facilidad probatoria), la cual constituye "un medio para flexibilizar, manera excepcional, la rigidez de la regla general de distribución de la carga probatoria recogida en el artículo $196^{\circ}$ del Código Procesal Civil” (Campos, 2012-2013, p.201).

Del mismo, en algunas resoluciones, los mismos órganos resolutores han considerado que la carga de la prueba respecto a los datos consignados en la declaración jurada presentada por el contribuyente le corresponde a éste, en tanto están obligados a 
ser veraces en las declaraciones de tributos que presentan (principio de autodeterminación).

De lo anteriormente expresado, se evidencia que los mencionados órganos resolutores no tienen claro cuál es la norma supletoria aplicable o el principio que sustenta la determinación de la carga de prueba en el procedimiento de fiscalización, lo que demuestra que resulta necesario regular a quién le corresponde la carga de la prueba en dicho procedimiento, a la Administración Tributaria o al contribuyente, y sobre qué aspecto de la determinación de la obligación tributaria, a fin de que éstos conozcan con antelación dicha carga, generándose una adecuada seguridad jurídica dentro del referido procedimiento y evitándose pronunciamientos disimiles y contrapuestos por los referidos órganos resolutores.

En este punto resulta necesario resaltar que el principio inquisitivo si bien nació en el proceso judicial fue trasladado en sus mismos términos al procedimiento administrativo, el cual se encuentra recogido en el artículo IX del Título Preliminar de la LPAG, la cual de acuerdo a la Tercera Disposición Complementaria Final de la misma ley, es aplicable supletoriamente a los procedimientos existentes en cuanto no la contradigan o se opongan ${ }^{16}$, tales como el de fiscalización tributaria. Sin embargo, de la jurisprudencia detallada en el capítulo anterior, se aprecia que tanto el Tribunal Fiscal como el Poder Judicial y el Tribunal Constitucional aplican también el principio dispositivo para la resolución de las controversias tributarias así como el de autodeterminación y facilidad probatoria.

Por otro lado, revisando las reglas de la carga de la prueba establecidas en otros ordenamientos jurídicos, hemos apreciado que, al igual que la jurisprudencia peruana, establecen sistemas compartidos de la carga de la prueba o la atribuyen únicamente a la Administración Tributaria o al contribuyente, sustentadas en principios que nacieron dentro del proceso judicial (principio dispositivo, inquisitivo y facilidad probatoria) o del carácter autodeclarativo de la obligación tributaria (principio de autodeterminación).

\footnotetext{
${ }^{16}$ Tercera Disposición Complementaria Final.- Integración de procedimientos especiales

"La presente Ley es supletoria a las leyes, reglamentos y otras normas de procedimiento existentes en cuanto no la contradigan o se opongan, en cuyo caso prevalecen las disposiciones especiales".
} 


\subsection{Postulados para establecer las reglas de la carga de la prueba en el procedimiento de fiscalización}

A fin de establecer las reglas de la carga de la prueba en el procedimiento de fiscalización en nuestra legislación, consideramos que es importante considerar los siguientes postulados:

\subsubsection{Las reglas de la carga de la prueba se establecen de acuerdo a la materia que regulan y el tipo de procedimiento a seguir}

"La distribución de la carga de la prueba en el caso particular depende la estructura de la relación material a decidirse". (Rosenberg, 1956, p.4).

Es decir, a efectos de establecer tales reglas, debe considerarse que el fin del procedimiento de fiscalización es determinar la correcta obligación tributaria, que es una de Derecho Público, sea que coincida con lo declarado por el contribuyente o no.

Si la actividad de acreditación de hechos que se desarrolla, en el procedimiento administrativo cuenta, como hemos visto, con importantes singularidades en su comparación con la que se desarrolla en el proceso", resulta razonable "que esas singularidades han de dejarse sentir en la definición de su régimen jurídico”. “(...) no existen reglas válidas y uniformes para toda clase de procedimientos. La extraordinaria diversidad que los preside muestra, por el contrario, la absoluta necesidad de efectuar distinciones según determinados criterios”. Así, por ejemplo, cabe diferenciar los procedimientos "por el papel que en ellos corresponde a la Administración" (procedimientos triangulares y "procedimientos en los que la Administración resuelve frente a una sola parte interesada"); por el impulso que da inicio al procedimiento (de oficio o a solicitud de parte); y por el objeto del procedimiento ("limitativos de derechos y procedimientos autorizatorios o concesionales") (Barrero, 2006, pp. 72 y 192).

En este punto, cabe anotar que si bien es indudable que la institución de la prueba y el proceso, donde ella se desarrolla, tienen un desarrollo más avanzado en sede jurisdiccional, también lo es, que el derecho administrativo, del cual forma parte el procedimiento de fiscalización, tiene una naturaleza y fines distintos, conforme se ha expuesto en el capítulo precedente. Por tal motivo, las reglas de la carga de la prueba deben tener en cuenta justamente las características propias del procedimiento de fiscalización, a saber, que es un procedimiento iniciado de oficio por la Administración 
Tributaria a fin de determinar la correcta obligación tributaria de los contribuyentes, para lo cual se encuentra premunida de amplias facultades y que el contribuyente se encuentra obligado a proporcionarle la información que requiera en cumplimiento de ficha función.

\subsubsection{Las reglas de la carga de la prueba se determinan dinámicamente durante el curso del procedimiento de fiscalización}

Además, la carga de la prueba "se determina no sólo por la situación inicial del proceso, sino por circunstancias posteriores", toda vez que "en el proceso ocurre un verdadero diálogo probatorio, y a medida que se presentan réplicas y contrarréplicas, e incluso como resultado de las pruebas que se van reuniendo, las partes modifican su situación procesal y el riesgo de la falta de prueba va pasando alternativamente de una a la otra". (Echeandía, 2012, p. 428).

En efecto, el proceso al igual que el procedimiento de fiscalización no es estático sino dinámico, comprendido por una serie de actuaciones probatorias efectuadas tanto por el contribuyente como por la Administración Tributaria con el fin de sustentar sus afirmaciones, hasta llegar al resultado final con la emisión de la resolución correspondiente que contiene la determinación de la obligación tributaria .

Conforme a lo indicado, en el procedimiento de fiscalización dependiendo de las actuaciones probatorias efectuadas, la carga de la prueba se atribuirá dinámicamente en un determinado momento al contribuyente o, en su caso, a la Administración Tributaria.

\subsection{Aplicación supletoria de las normas del Código Procesal Civil, de la LPAG o necesidad de establecer reglas propias en el procedimiento de fiscalización}

Como hemos revisado en el Capítulo II del presente trabajo, entre el proceso civil y el procedimiento administrativo existen importantes diferencias que inciden en la determinación de las reglas de la carga de la prueba en uno u otro. El proceso comparecen dos partes en igualdad de condiciones ante un tercero imparcial (juez), mientras que en el procedimiento administrativo, por lo general, se desarrolla entre el interesado y la Administración (juez y parte); el primero se encuentra regido por el principio dispositivo y tiene como fin resolver el litigio que enfrenta a dos partes que 
aportan las pruebas para sustentar sus afirmaciones, y el segundo, por el principio inquisitivo o de oficialidad, que obliga a la Administración a realizar la actividad probatoria necesaria para sustentar los actos que emita al culminar un procedimiento.

Sin embargo, como hemos podido apreciar, el Tribunal Fiscal, el Poder Judicial y el Tribunal Constitucional, recurren indistintamente a las normas del Derecho Procesal Civil y del Derecho Administrativo, para tratar de delimitar las reglas de la carga de la prueba aplicables al procedimiento de fiscalización, sin tener en cuenta, las singularidades que existen entre el proceso y el procedimiento administrativo, lo cual trae como consecuencia, un reparto de la carga de la prueba inadecuada y, por ende, la emisión de cuestionadas resoluciones por dichos órganos.

Por lo expuesto, compartimos la tesis de la autonomía de la prueba en el procedimiento administrativo respecto de la prueba procesal, por lo que consideramos que no corresponde aplicar de plano las reglas de la carga de la prueba en materia procesal civil al procedimiento administrativo en general y en particular al de fiscalización.

En efecto, a fin de determinar las reglas de la carga de la prueba en el procedimiento de fiscalización, debe tenerse en cuenta que a diferencia del proceso civil, que se inicia a instancia de parte (proceso dispositivo), en el cual existe un tercero imparcial (juez) que resuelve en base a las pruebas aportadas por cada una de las partes en litigio, las que tienen la carga de la prueba de demostrar la veracidad de sus pretensiones; el procedimiento de fiscalización es un procedimiento administrativo iniciado de oficio, conforme al cual la Administración Tributaria verifica el cumplimiento de las obligaciones tributarias de los contribuyentes; esto es, ambos procedimientos tienen naturaleza distinta, uno de carácter dispositivo y otro iniciado de oficio. Además, mientras que en el proceso civil se discuten o se buscan proteger derechos particulares, en el procedimiento de fiscalización, la Administración Tributaria es gestora de la protección de un interés público, esto es, verificar el cumplimiento de las obligaciones tributarias por los contribuyentes a fin de garantizar la obtención de la recaudación tributaria que el Estado requiere para satisfacer las necesidades públicas de la ciudadanía.

Del mismo modo, somos de la opinión que si bien en la LPAG se ha establecido que la carga de la prueba se rige por el Principio de Impulso de Oficio, consideramos 
que de la interpretación de dicho principio no puede sostenerse que la carga de la prueba en el procedimiento de fiscalización le corresponda únicamente a la Administración Tributaria. Por el contrario, del Principio de Impulso de Ofício podemos concluir que por la naturaleza del procedimiento de fiscalización (procedimiento iniciado de oficio), la Administración Tributaria está obligada a "impulsar", diligenciar, requerir u obtener los medios probatorios necesarios para discernir el aspecto fiscalizado; más aún cuando, en principio, al ejercer su facultad de fiscalización ésta se basa en los datos obtenidos de las autodeterminaciones o declaraciones juradas de los contribuyentes, quienes al haber consignado voluntariamente dichos datos, se entiende que deberían tener el sustento respectivo de los mismos.

Por lo expuesto, consideremos que independientemente de lo regulado en el Código Procesal Civil y la LPAG, así como lo establecido por la jurisprudencia nacional antes detallada, el presente trabajo tiene como objetivo establecer las reglas de la carga de la prueba en el procedimiento de fiscalización, teniendo en cuenta que mediante éste la Administración Tributaria verifica la determinación de la obligación tributaria contenida en la declaración tributaria presentada previamente por el contribuyente, a fin de dilucidar si ésta se encuentra acorde con lo establecido en la normatividad tributaria, supuesto en el cual, la confirmará o, en caso no corresponda a dicha normatividad, efectuará una nueva determinación, incrementando la obligación tributaria.

En tal sentido, a continuación explicaremos cómo deben establecerse reglas propias sobre la carga de la prueba en el procedimiento de fiscalización considerando sus características y fin propios, recogiendo, de ser el caso, los principios expuestos en el Capítulo II del presente trabajo.

\subsection{Reglas de la carga de la prueba aplicables al procedimiento de fiscalización}

Como sabemos, la determinación de la obligación tributaria se efectúa, en principio, por el contribuyente a través de la presentación de la declaración jurada, por lo que somos de la opinión que éste tiene la carga de la prueba de sustentar ante la Administración Tributarias que la información consignada en la misma es conforme a la realidad de los 
hechos, esto es, que tanto los ingresos y deducciones declaradas por su parte corresponden a las operaciones efectivamente realizadas por él.

En esa línea de criterio, consideramos que resulta aplicable a las reglas de la carga de la prueba el Principio de Autodeterminación, que tiene aplicación preponderante en Grecia.

Ahora, cabe anotar que de acuerdo a la jurisprudencia detallada en el Capítulo II del presente trabajo, se ha considerado que el contribuyente tiene que probar la determinación contenida en su declaración jurada debido a que se encuentra en mejores condiciones para hacerlo, lo cual podría confundirse con la aplicación del Principio de Facilidad Probatoria (Teoría de las Cargas Dinámicas de la Prueba). Sin embargo, nosotros entendemos que dicho principio no es el que justifica la referida carga de la prueba, sino el carácter autodeterminativo de la declaración jurada, cuyos datos son consignados voluntariamente por el contribuyente, es decir, constituyen una afirmación hecha por su parte, por lo que éste tiene la carga de probar que la determinación contenida en dicha declaración es conforme a la realidad.

En este punto, debemos precisar que el Principio de Facilidad Probatoria nació como una forma de flexibilizar la regla referida a que corresponde la carga de la prueba a quien afirma un hecho o a quien lo contradice, estableciendo que cuando quien tiene dicha carga se enfrenta a una situación de imposibilidad de cumplimiento de la misma, la carga de la prueba recae sobre la parte que está en mejores condiciones de hacerlo, a fin de resolver en base a la verdad de los hechos efectivamente acaecidos. Es decir, el mencionado principio constituye una excepción a la aplicación de la regla de la carga de la prueba basada en el principio dispositivo y parte de la doctrina incluso considera que es un supuesto de inversión de la carga de la prueba aplicada en situaciones de evidente desventaja para quien le correspondía probar, tales como temas de negligencia médica, derechos laborales o pensionarios, de forma tal que se atribuya la carga de la prueba a la contraparte que se encuentra en mejores condiciones para producirla a fin de mantener la igualdad de las partes y resolver con justicia el caso concreto.

Como se aprecia, el supuesto detallado en el párrafo precedente no se presenta cuando indicamos que el contribuyente tiene la carga de probar la determinación contenida en la declaración jurada que presentó, por lo que mal podría afirmarse que se 
trata de un supuesto de atribución de la carga de la prueba por facilidad probatoria del contribuyente.

Ahora bien, a nivel doctrinario se ha sostenido que en un procedimiento de fiscalización el contribuyente únicamente tendría deberes (de colaboración o deberes formales) y no cargas de la prueba, en la medida que el incumplimiento de la presentación de la información solicitada por el ente administrador de tributos acarrea una sanción, que es, por lo general, una multa.

Sobre el particular, debemos mencionar que en efecto de acuerdo al artículo $87^{\circ}$ del Código Tributario es obligación del contribuyente permitir el control por la Administración Tributaria presentando la información relacionada con hechos susceptibles de generar obligaciones tributarias; siendo que el incumplimiento de dicha obligación es sancionada con multa de acuerdo a lo dispuesto por el numeral 1 del artículo $176^{\circ}$ del mismo código.

Sin embargo, visto el mencionado deber desde la perspectiva de la obligación sustancial (tributo a determinar), es evidente que si el contribuyente no cumple con presentar la información que sustente los datos contenidos en su declaración jurada tributaria, tendrá como consecuencia desfavorable que éstos sean desconocidos por la Administración Tributaria, la que podrá modificar la determinación contenida en la referida declaración.

En tal sentido, la doctrina ha aceptado que "el deber general de colaboración con la Administración Tributaria que preside las relaciones entre ésta y los contribuyentes" y se traduce en la existencia de múltiples obligaciones formales de información y prueba a cargo de los contribuyentes". (Rodríguez-Bereijo, 2012, p.13).

Además, la preponderancia del mencionado deber en el ámbito fiscal "es tal que en cierto modo puede afirmarse que a través de ellos se lleva a cabo una distribución “encubierta" de la carga de la prueba, en el sentido formal o subjetivo del término". (Martens, citado por Bereijo, 2011, p.13).

A mayor abundamiento, debemos anotar que el fin de las sanciones no es recaudar ingresos en base a la capacidad contributiva del contribuyente sino desincentivar conductas ilícitas; en el caso de análisis, desincentivar que el contribuyente no colabore con la labor de fiscalización de la Administración Tributaria presentando la información solicitada por ésta; sin embargo, si asumimos que la no 
colaboración únicamente le generará a éste, una sanción pecuniaria (multa), y no incidirá en su perjuicio en la determinación de la obligación tributaria (carga de la prueba), el contribuyente podría asumir como más beneficioso el costo de la sanción de multa que por su propia naturaleza resulta menor a la cuantía de la obligación tributaria, que está determinada en base a su capacidad contributiva, lo cual lógica y razonablemente no puede ser aceptado por el ordenamiento jurídico.

En esa línea de criterio, el maestro Carnelutti enseña que, "al ser la prueba una operación de la cual depende en gran parte el costo y el rendimiento del proceso, se comprende que no quede abandonada a la libre actividad de los hombres que participan en ella, sino que, al contrario, el derecho tienda a regularla a fin de garantizar, del mejor modo sus resultados" (citado por Falcón, 2009, p.737).

Es decir, resulta necesario que el Derecho tienda a regular la actividad probatoria en un procedimiento a fin de que el resultado de éste no dependa del libre albedrío de las partes, máxime en un procedimiento como el de fiscalización, mediante el cual se determina la correcta obligación tributaria, en último término, se obtienen los recursos para cubrir las necesidad públicas de la sociedad.

En tal sentido, se aprecia que el hecho de presentar la documentación solicitada por el órgano administrativo, si bien constituye un deber, cuyo incumplimiento es ilícito $\mathrm{y}$, por ende, sancionado administrativamente; adicionalmente, y visto desde la perspectiva del fin para el cual se solicita dicha información (determinar la obligación tributaria), constituye una carga de la prueba para el contribuyente, cuyo incumplimiento le generará una consecuencia desfavorable determinada por el desconocimiento de la obligación tributaria que declaró.

Por tal motivo, consideramos que en el procedimiento de fiscalización al contribuyente sí le son atribuibles cargas de la prueba que se superponen a sus deberes de colaboración o deberes formales para con la Administración Tributaria.

Por otro lado, en relación a la carga de la prueba que le corresponde a la Administración Tributaria, cabe anotar que, conforme se ha expuesto en el Capítulo II del presente trabajo, la doctrina no es pacífica respecto a si ésta, en efecto, tiene una carga de la prueba, en tanto se considera que aquélla tendría en realidad un deber de probar sustentado en los principios del derecho administrativo de oficialidad o impulso de oficio, verdad material, legalidad, entre otros. 
Sobre el particular, cabe anotar que en puridad y de acuerdo a los abundantes estudios efectuados al respecto sobre la carga de la prueba en procesos inquisitivos como el penal, en efecto la Administración Tributaria como organismo que forma parte del Estado y que cumple una función pública de interés social, llámese la verificación del cumplimiento de las obligaciones tributarias por parte de los contribuyentes, regida por los principios administrativos antes indicados, tiene el deber de probar los hechos que sustentan la determinación tributaria que efectúe en el marco de un procedimiento de fiscalización regido además por los deberes de colaboración de los contribuyentes y las amplias facultades otorgadas por el Código Tributario para tales efectos.

No obstante, el referido deber de probar de la Administración Tributaria se traduce en la práctica en una carga de la prueba de la que ésta es titular, tan es así, que incluso los ordenamientos jurídicos de diversos países así como el Tribunal Fiscal y el Poder Judicial han considerado que aquélla tiene una verdadera carga de la prueba respecto de determinados hechos, supuesto que ha incidido e incide en la forma en que dichos órganos vienen resolviendo las controversias tributarias que se les presentan.

Por tal motivo, considerando los fines del presente trabajo, esto es, establecer con claridad quién debe presentar las pruebas y respecto de qué aspecto, somos de la opinión que en el procedimiento de fiscalización, la Administración Tributaria también tiene una carga de la prueba que debe cumplir a cabalidad a fin de no menoscabar derechos de los contribuyentes o generarles incertidumbres jurídicas.

De este modo, de manera similar al caso de los contribuyentes, la Administración Tributaria tiene cargas de la prueba que se superponen a sus deberes de corroboración de los hechos que sustentan sus decisiones.

Así, la Administración Tributaria tendrá la carga de la prueba respecto de los hechos nuevos que alegue en relación con la determinación efectuada por el contribuyente cuando éstos constituyan mayores ingresos, valiéndose para tal fin de los deberes de colaboración que tiene el contribuyente de presentar la información que aquélla requiera, así como de la información que pueda obtener de su base de datos o que requiera a terceros vinculados a las operaciones que efectúa el contribuyente.

Como se aprecia, la carga de la prueba atribuida a la Administración se sustenta en la máxima del principio dispositivo según el cual, quien afirma un hecho tiene la carga de probarlo, el cual consideramos aplicable al procedimiento de fiscalización, 
toda vez que aquélla cuenta con las facultades para cumplir dicha carga, del mismo modo en que el contribuyente puede probar aquello que ha afirmado a través de su declaración jurada.

Conviene anotar al respecto, que frente a la evidente ventaja del contribuyente de contar con las pruebas que sustentan las operaciones que el mismo ha realizado, es decir, su conexión directa con las pruebas que han dado lugar al nacimiento de la obligación tributaria; la Administración Tributaria no participa en la generación de la materia imponible sino únicamente la verifica como parte de la función pública que realiza, por lo que para igualar tal situación, el ordenamiento jurídico ha premunido a la misma de amplias facultades de fiscalización, las que deben ser utilizadas razonadamente y servir únicamente para cumplir su finalidad de sustentar la correcta determinación tributaria, mas no trasladar al contribuyente la carga de la prueba de la que es titular.

Por otro lado, podría darse el caso en el cual el contribuyente decida no cumplir con sus deberes de colaboración de presentar la información requerida por la Administración Tributaria, en razón de que resulte perjudicial a sus intereses, por ejemplo, si éstos van a dar lugar a una mayor determinación de la obligación tributaria que declaró. En tal sentido, consideramos que en dicho supuesto, el riesgo de la falta de la prueba se trasladaría al contribuyente, toda vez que el procedimiento de fiscalización se establece a fin de garantizar el cumplimiento de un interés público, esto es, el sostenimiento de las cargas públicas que se logra con la obtención de la recaudación tributaria y no puede quedar a merced de la libre voluntad de colaborar del contribuyente.

Así, la doctrina alemana ha propuesto completar la regla básica de la carga de la prueba, con una teoría que trata de distribuir los riesgos probatorios en función de la esfera de responsabilidad de la que provenga la generación del riesgo probatorio y a quien es atribuible dicha responsabilidad, si a la Administración o al contribuyente. (Rodriguez-Bereijo, 2012, pp.16-17)

Como señala Rodriguez-Bereijo (2012), esta teoría proporciona "reglas que desarrollan la regla general de distribución de la carga de la prueba del ámbito tributario, completando los resultados de una mera distinción entre circunstancias constitutivas o que incrementan la obligación tributaria" (carga de la prueba de la 
Administración Tributaria) "y circunstancias impeditivas o excluyentes" (carga de la prueba del contribuyente), así:

Por lo que respecta a las circunstancias constitutivas o que incrementan la obligación tributaria, materia de nuestro interés en este punto del presente trabajo:

- En aquellos casos en que la falta de prueba sea debido a una falta de colaboración del contribuyente, el riesgo de la prueba recae sobre el contribuyente. Para esos casos, el ordenamiento tributario hace posible la liquidación de la deuda tributaria basada en un menor rigor probatorio, a través de la estimación ${ }^{17}$, que conduce a una forma especial de apreciación de la prueba.

- En los casos, en cambio, en que la falta de la prueba no se deba a una falta de colaboración del contribuyente, el riesgo de la (falta) de la prueba ha de recaer sobre la Administración Tributaria.

En palabras de Rodriguez-Bereijo (2012), se trata, en definitiva, de que el sujeto a quien se le atribuye el riesgo derivado de la falta de prueba sea el mismo sujeto a quien es imputable, subjetiva u objetivamente, el cumplimiento o incumplimiento de los deberes de la prueba, en la medida o grado que venga exigido en cada caso. (pp. 16-17)

Como podemos apreciar, las reglas de la carga de la prueba en Alemania se sustentan en principio en las reglas civiles sustentadas en el principio dispositivo matizadas con el riesgo de la falta de prueba debido a la falta de colaboración del contribuyente.

No obstante, como hemos expuesto en párrafos precedentes, consideramos que las reglas de la carga de la prueba deben establecerse considerando que el procedimiento de fiscalización tiene por finalidad verificar la correcta determinación de la obligación tributaria, finalidad disímil a la del proceso civil en el cual nació la regla básica procesal de la que parte la doctrina alemana y cuyo fin primigenio era resolver un conflicto de interés entre particulares en igualdad de condiciones.

En efecto, la determinación de la obligación tributaria, en principio, es efectuada por el contribuyente a través de la declaración jurada, la cual comprende tanto los hechos constitutivos de la obligación tributaria como aquellos que disminuyen o

${ }^{17}$ Presunción tributaria. 
extinguen la misma, por lo que en virtud del principio de autodeterminación, le corresponde a éste la carga de la prueba de los referidos hechos contenidos en su declaración jurada.

En tal sentido, consideramos que las dos reglas antes esbozadas por la doctrina alemana, deben aplicarse en un momento posterior al que corresponde a la carga de la prueba del contribuyente de sustentar los datos consignados en su declaración jurada. Es decir, si el contribuyente no cumple con colaborar con la Administración Tributaria presentando los documentos o pruebas requeridas por ésta, respecto de los hechos constitutivos o que incrementan la obligación tributaria, traducido en su deber de colaboración, el riesgo de la falta de prueba recaerá en él; por lo que la Administración podrá determinarlos en base a estimaciones o presunciones.

En el supuesto contrario, esto es, si el contribuyente cumple con presentar la documentación o pruebas requeridas en cumplimiento de su deber de colaboración con la Administración Tributaria, el riesgo de los hechos constitutivos o que incrementan la obligación tributaria recaerá en la Administración Tributaria.

De lo expuesto, se concluye que en el procedimiento de fiscalización, la carga de la prueba le corresponde tanto a la Administración Tributaria como a los contribuyentes, recogiendo los principios de autodeterminación (en el caso del contribuyente) y dispositivo (en el caso de la Administración Tributaria) detallados en el Capítulo II del presente trabajo así como la doctrina y normatividad aplicable en otros ordenamientos jurídicos.

\subsection{Hasta dónde corresponde probar al contribuyente la determinación contenida en su declaración jurada}

Llegado a este punto, nos preguntamos ¿Hasta dónde le corresponde probar al contribuyente la determinación de la obligación tributaria consignada en su declaración jurada? ¿Cuándo se considera que ha cumplido con su carga de la prueba?

En principio, cabe anotar que la forma de valoración de los medios de prueba presentados por el contribuyente en el procedimiento de fiscalización o determinación del umbral de certidumbre no constituye un fin en sí mismo del presente trabajo, sin embargo, consideramos importante esbozar algunos puntos al respecto al encontrase relacionados con nuestro tema de investigación. 
En efecto, las referidas interrogantes están relacionadas con el aspecto objetivo de la carga de la prueba, es decir, con la regla de juicio que orienta a la Administración Tributaria respecto a cómo debe determinar la obligación tributaria en caso no se llegue a dicho estándar, quien debe asumir el riesgo de su incumplimiento.

El punto de partida para la carga de la prueba se sitúa en la duda del juez u órgano encargado de la aplicación del derecho en el momento de dictar resolución, cuando no ha logrado la certidumbre necesaria en torno al supuesto fáctico que debe enjuiciar generalmente por insuficiencia probatoria. Pero ¿cuánto se necesita para poder considerar probado un hecho? Esto es lo que se ha denominado dosis de prueba, coeficiente de prueba o standard of proof en el derecho anglosajón, que es el nivel de evidencia necesaria para satisfacer la carga primaria de la prueba y esta es aquella que la ley atribuye a una de las partes ${ }^{18}$.

Ahora bien, coincidimos con Bereijo (2011) cuando precisa que la determinación de lo que denominaremos estándar de prueba mínima, se encuentra relacionado con el tipo de proceso en que nos encontremos, "pues en cada ámbito procesal opera un estándar diferente en funciones de los valores que están en juego". (p.9).

Así, en la doctrina estadounidense, tenemos que son tres los standard: i) preponderancia de pruebas (utilizado para los casos civiles en general); ii) prueba clara y convincente (utilizado para casos especiales, como los de familia) y iii) prueba más

${ }^{18}$ La determinación de este coeficiente de prueba está en relación con el tipo de ámbito procesal en que nos encontremos, pues en cada ámbito procesal opera un estándar diferente, en función de los valores jurídicos en juego. (Rodríguez-Bereijo, 2012, p. 15)

Si compramos el proceso civil peruano, heredero de la tradición romano-germánica o de la tradición Civil Law, como se nos suele llamar; con el proceso civil norteamericano, uno de los sistemas herederos del Common Law. El ejercicio será especialmente útil porque nos permitirá entender cómo funcionan la carga de la prueba en un sistema procesal especialmente complejo, en el que las cargas de la prueba actúan en diferentes etapas del proceso. Ello contrasta con nuestro sistema, en el que la carga de la prueba son una preocupación del Juez solo al momento de sentenciar.

La carga de la prueba en el proceso penal norteamericano es diferente a la carga de la prueba en su propio proceso civil. En el proceso penal, es sobradamente conocido el "beyond-a-reasonable-doubt" de la doctrina anglosajona, en cuya virtud no puede existir ninguna duda razonable o probabilidad prevalente de la culpabilidad del procesado. Sin embargo en el proceso civil, en cambio, la doctrina anglosajona ha acuñado la regla "preponderance of the evidence"o "balance of probabilities", como regla general y con excepciones, se requiere que el jurado encuentre que los hechos que sustentan la pretensión, a partir de pruebas, queden verificados con un probabilidad mayor al cincuenta por ciento (50\%). En nuestro sistema, las cosas son más sencillas: el estándar de convicción que el juzgador necesita para declarar fundada una pretensión civil es el mismo que el necesario para declarar fundada una pretensión punitiva, es decir, para declarar culpable al procesado. En ambos casos se requiere que las pruebas generen mayor convicción de que la pretensión es fundada que convicción de que no es fundada. (Rivarola, 2005, pp. 122-123). 
allá de cualquier duda razonable (utilizado en el ámbito penal). A partir de esos grados, que dependen del derecho material, será posible considerar una hipótesis como probada o no (como se citó en Gonzales, 2014, p.395-396).

Ahora bien, como sabemos el procedimiento de fiscalización es uno iniciado de oficio a fin de cumplir un fin de interés general o público, al igual que el proceso penal, el primero, verificar la correcta determinación tributaria, y el segundo, determinar la responsabilidad penal del inculpado.

Sin embargo, las diferencias entre el procedimiento de fiscalización y el proceso penal se evidencian inmediatamente si recordamos que en este último rige el principio indubio pro reo, que significa que determinar la responsabilidad penal requiere una certeza casi absoluta, de modo tal que si el Ministerio Público o el Juez no han logrado tal determinación, la duda favorece al inculpado, es decir, se considera que no tiene responsabilidad alguna debiendo absolvérsele de toda imputación.

En este punto, conviene anotar que si bien en el procedimiento administrativo rige el principio de presunción de veracidad establecido en el numeral 1.7 del artículo IV de la LPAG, según el cual en la tramitación del procedimiento se presume que los documentos y declaraciones formulados por los administrados en la forma prescrita por dicha ley, responden a la verdad de los hechos que ellos afirman; dicha presunción admite prueba en contrario de forma menos exigente que el indubio pro reo, toda vez que en el procesos penal se discuten derechos sustanciales, tal como la libertad personal.

En tal sentido, no corresponde aplicar el nivel de exigencia probatoria establecido para el proceso penal en el procedimiento de fiscalización, siendo más razonable y conveniente, considerando que la determinación de la obligación tributaria es realizada en principio por el contribuyente en base a las operaciones por él realizadas, aplicar el principio de preponderancia de pruebas, esto es, efectuar un análisis conjunto y razonado de las pruebas presentadas y establecer si a través de éstas, el contribuyente ha probado su afirmación.

Sobre el particular, debemos reiterar que establecer en qué consiste el mencionado estándar de prueba mínimo, excede los fines del presente trabajo, en tanto implica la revisión de la normatividad específica sobre la materia o aspecto a probar. 
Sin perjuicio de lo expuesto, consideramos que el estándar probatorio mínimo debe respetar las siguientes reglas:

- Sólo puede exigirse al contribuyente probar sus afirmaciones en base a la documentación que está obligado a mantener y no aquella que obre en poder de terceros.

- Debe considerarse la naturaleza de la operación a probar y su carácter razonable o normal en el giro del negocio analizado ${ }^{19}$.

- Si la ley ha establecido con qué documento debe probarse un determinado hecho y el contribuyente cumple con presentarlo, la Administración Tributaria será la obligada a probar en base a la información con que cuente en base a sus sistemas informáticos u obtenida de terceros, que el hecho en cuestión no corresponde efectivamente a la realidad de los hechos.

Adicionalmente, cabe precisar que la determinación efectuada en el procedimiento de fiscalización no es definitiva, se encuentra sujeta a revisión por parte del órgano de reclamación (que es parte de la Administración Tributaria), del Tribunal Fiscal, el Poder Judicial o el Tribunal Constitucional. Por tal motivo, la respuesta de hasta dónde se debe probar o en qué consiste en estándar probatorio mínimo se evaluará en el caso concreto y dependerá de la evaluación del órgano respectivo.

\footnotetext{
${ }^{19}$ Cabe precisar que según el profesor Villanueva, en Estados Unidos existe un criterio que complementa la carga de la prueba, según el cual, si el contribuyente presenta un caso verosímil, un caso creíble, razonable, la carga de la prueba se invierte hacia la Administración Tributaria. (SNMPE, 2015, p. 67).
} 


\section{CONCLUSIONES}

- El derecho a la prueba constituye un derecho fundamental que forma parte del derecho al debido proceso, cuyo contenido esencial comprende el derecho a ofrecer medios probatorios y a que éstos sean debidamente valorados. Sin embargo, dicho derecho no es absoluto, encontrándose limitado por las disposiciones constitucionales así como por aquellas establecidas en leyes ordinarias.

- En el cumplimiento de la carga prueba dentro del procedimiento de fiscalización, la Administración Tributaria está obligada a respetar los derechos fundamentales establecidos en la Constitución Política del Perú tanto expresamente como aquellos que se desprenden del respeto y protección de la dignidad humana.

- A fin de determinar las reglas de la carga de la prueba aplicables al procedimiento de fiscalización, debe tenerse en cuenta que a diferencia del proceso civil, que se inicia a instancia de parte (proceso dispositivo), en el cual existe un tercero imparcial (juez) que resuelve en base a las pruebas aportadas por cada una de las partes en litigio, las que tienen la carga de la prueba de demostrar la veracidad de sus pretensiones; el procedimiento de fiscalización es un procedimiento administrativo iniciado de oficio, conforme al cual la Administración Tributaria verifica el cumplimiento de las obligaciones tributarias y formales de los contribuyentes; esto es, ambos procedimientos tienen naturaleza distinta, uno de carácter dispositivo y otro iniciado de oficio. Por tal motivo, no corresponde aplicar directamente las normas de la carga de la prueba del proceso civil al procedimiento de fiscalización.

- Por el Principio de Impulso de Oficio, que fue establecido considerando la naturaleza del procedimiento de fiscalización (procedimiento iniciado de oficio), la Administración Tributaria está obligada a "impulsar", diligenciar, requerir u obtener los medios probatorios necesarios para discernir el aspecto fiscalizado. Por tal motivo, se ha dotado a la Administración Tributaria de amplias facultades de fiscalización establecidas en el artículo $62^{\circ}$ del Código Tributario. Sin embargo, de la interpretación de dicho principio no se desprende que la carga de la prueba en el 
procedimiento de fiscalización le corresponda únicamente a la Administración Tributaria; sino mas bien que le corresponde realizar las comprobaciones necesarias a efectos de sustentar los resultados de la fiscalización, sea mediante la determinación de deuda tributaria o a través de la confirmación de la autodeterminación efectuada por el contribuyente.

- En función de lo indicado, no corresponde aplicar de plano las reglas de la carga de la prueba establecidas en el Derecho Procesal Civil y en la Ley del Procedimiento Administrativo General al procedimiento de fiscalización.

- Las reglas de las carga de la prueba en el procedimiento de fiscalización deben establecerse considerando las características propias del mismo, esto es, que tiene por finalidad determinar la correcta obligación tributaria en un marco de amplias facultades otorgadas por el legislador a la Administración Tributaria y deberes de colaboración del contribuyente para tales efectos.

- A la luz del Principio de Autodeterminación, corresponde al contribuyente la carga de la prueba respecto de los datos y hechos consignados en su declaración jurada, esto es, de la obligación tributaria que voluntariamente ha determinado en función a las operaciones económicas por él conocidas y realizadas. Cabe precisar que esta regla no corresponde a la aplicación del Principio de Facilidad Probatoria, el cual se ha aplicado en los procesos judiciales en supuestos en los cuales el sujeto al que le corresponde la carga de la prueba se encuentra en una situación de imposibilidad de cumplimiento, y a fin de que se mantenga la igualdad de las partes y se resuelva una controversia con justicia, se traslada la carga de la prueba al sujeto que se encuentra en mejores condiciones para asumirla.

- En función al principio dispositivo, según el cual, aquél que alega un hecho debe probarlo, corresponde a la Administración Tributaria la carga de la prueba de los hechos constitutivos o que incrementan la obligación tributaria distintos a los consignados por el contribuyente en su declaración jurada, para tal efecto, éste último está obligado a cumplir con su deber de colaboración con aquélla, proporcionándole la documentación que requiera para cumplir con la finalidad del procedimiento de fiscalización, esto es, determinar la correcta obligación tributaria.

- Corresponde aplicar para este último supuesto, lo establecido en Alemania respecto a que si el contribuyente no cumple con colaborar con la Administración Tributaria 
presentando los documentos o pruebas requeridas por ésta, respecto de los hechos constitutivos o que incrementan la obligación tributaria, traducido en su deber de colaboración, el riesgo de la falta de prueba recaerá en él; por lo que la Administración podrá determinarlos en base a estimaciones o presunciones. En el supuesto contrario, esto es, si el contribuyente cumple con dicho deber, el riesgo de los hechos constitutivos o que incrementan la obligación tributaria recaerá en la Administración Tributaria.

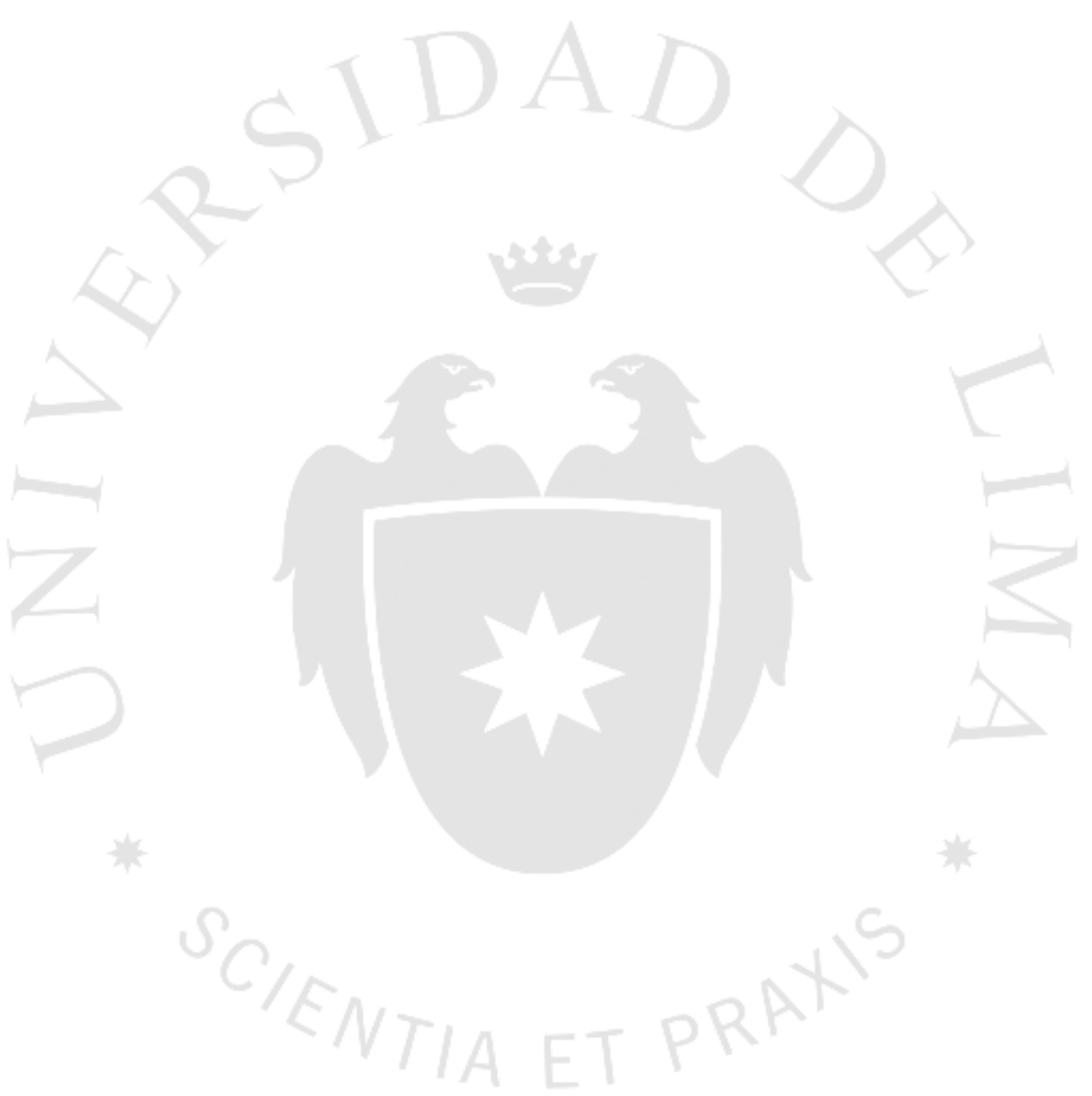




\section{RECOMENDACIONES}

A continuación detallaremos las recomendaciones:

- Regular expresamente en el Código Tributario las reglas de la carga de la prueba, a fin de que la Administración Tributaria y los contribuyentes tengan certeza respecto de los hechos que les corresponde probar.

- Recoger las reglas de la carga de la prueba desarrolladas en el presente trabajo referidas a la aplicación del Principio de Autodeterminación para el caso del contribuyente y del Principio Dispositivo para el caso de la Administración Tributaria. 


\section{REFERENCIAS}

Barrero, C. (2006). La prueba en el procedimiento administrativo. (3a ed.). Navarra, España: Editorial Aranzadi.

Brewer-Carias, A. (2003). Principio del procedimiento administrativo en américa latina. (1a ed.). Bogotá, Colombia: Legis.

Campos, W. (2012-2013). Aplicabilidad de la teoría de las cargas probatorias dinámicas al proceso civil peruano. Apuntes iniciales. Revista Oficial del Poder Judicial, 6-9, 201-214.

Calvo, O. (2002) Curso de derecho financiero I Derecho Tributario Parte General (6 ${ }^{\mathrm{a}}$ ed.) Madrid, España: Thompson Civitas

Carnelutti, F. (1952). Estudios de Derecho Procesal (1 $1^{\mathrm{a}}$ ed.), Buenos Aires, Argentina: Ediciones Jurídicas Europa- América

Couture, E. (1973). Fundamentos del Derecho Procesal Civil (3 $3^{\mathrm{a}}$ ed.) Buenos Aires, Argentina: Ediciones Depalma.

Del Padre, F. (2012). La prueba en el derecho tributario. ( $3^{\text {a }}$ ed.). Lima, Perú: Editora y Librería Jurídica Grijley.

Donaires, P. (2014) Aplicación jurisprudencial de la doctrina de las cargas probatorias dinámicas. Derecho y Cambio Social. (35) 1-26.

Duran, R. (2009). Alcances del derecho a la prueba en materia tributaria especial referencia a los procedimientos de fiscalización y contencioso-tributario (primera parte). Análisis Tributario, XXII (257), 9-12.

Duran, R. (2009). Alcances del derecho a la prueba en materia tributaria especial referencia a los procedimientos de fiscalización y contencioso-tributario (segunda parte). Análisis Tributario, XXII (262), 10-12.

Echeandia, D. (2012). Teoría general de la prueba judicial (15a ed.).Colombia: Temis.

Escribano, F., Blume, E., Gamba, C., Bravo, J., Yacolca, D., y otros (2010) Introducción al Derecho Financiero y Tributario (1a ed.), Lima, Perú Jurista Editores

Eto, G. (2011). El derecho procesal constitucional: su desarrollo jurisprudencial. (3a ed.). Bogotá, Colombia: Editorial Temois.

Eto, G. (2011). El desarrollo del derecho procesal constitucional a partir de la jurisprudencia del tribunal constitucional peruano. (4a ed.). Lima, Perú: Editorial Adrus. 
Falcon, E. (2009) Tratado de la prueba (2 ${ }^{\mathrm{a}}$ ed), Buenos Aires, Argentina: Editorial Astrea

Folco, C. (2012) Medios de prueba en el procedimiento tributario.

Gaceta civil y procesal (2013). La admisibilidad de la carga probatoria en el proceso civil. Gaceta civil y procesal, -- (4), 175-186.

Garcia de Enterría, E. y Tomás-Ramón, F. (2006). Curso de derecho administrativo. (1a ed. Peruana, en base a la $11^{\mathrm{a}}$ ed.). Lima, Perú: Palestra Editores

Gamba, C. (2005). Los derechos y garantías del contribuyente en el procedimiento de fiscalización o verificación. Actualidad Jurídica, (141) 206.

Gonzales, J. (2001). El derecho a la tutela jurisdiccional. (3a ed.). Madrid, España: Civitas Ediciones.

Gonzales, R. (2014). Constitucionalismo y proceso tendencias contemporáneas. (1a ed.). Lima, Perú: Ara Editores.

Guzman, C. (2005). La Carga de la prueba en el procedimiento administrativo general. Actualidad Jurídica, -- (134), 169-172.

Hernández, R. (2006). Derechos fundamentales y jurisdicción constitucional. (1a ed.). Lima, Perú: Jurista Editores.

Hinostroza, A. (2010) Derecho procesal civil. Lima, Perú: Jurista editores.

Hurtado, M. (2009). Fundamentos de Derecho Procesal (1ª ed.), Lima, Perú: Idemsa.

Martinez, A. (2005). La garantía del contenido esencial de los derechos fundamentales. Trujillo, Perú: Tabla XIII Editores.

Michelli, G. (1989). La carga de la prueba (1ª ed.), Bogotá, Colombia: Editorial Themis.

Montero, J. (2011) La prueba en el proceso civil (6 $6^{\mathrm{a}}$ ed.), Navarra, España: Thompson Reuters.

Moreano, C. (2015) Algunas reflexiones sobre la atribución de la carga de la prueba en materia tributaria. Análisis Tributario, XXXVIII (329), 18-24.

Morón, J. (2015). Comentarios a la ley del procedimiento administrativo general. (11a ed.). Lima, Perú: Gaceta Jurídica.

Pico, J. (2012). Las garantías constitucionales del proceso. (2a ed.). Barcelona, España: Librerías Bosch.

Priori, G., Pérez-Cruz, A., Montezuma, A., Mendoza, A., Quiroga, A., Lorca, A.,... Doig, Y. (2013). Proceso y constitución: las garantías del proceso justo. (1a ed.). Lima, Perú: Palestra Editores. 
Rivarola, D. (2015) ¿Actori incumbit probatio? Presunciones y cargas de la prueba repensadas: common law versus civil law. Themis, -- (51), 121-132.

Rodriguez-Bereijo, M. (2011) La carga de la prueba en el derecho tributario: aplicación en las normas tributarias anti-abuso y en la doctrina del TJUE. RCyT. CEF, (344), 5-50.

Rodriguez-Bereijo, M. (2012) La documentación de las operaciones vinculadas ¿cuestión de obligación o carga de la prueba para el contribuyente? (primera parte). Análisis Tributario, XXV (293), 12-17.

Rosenberg, L. (1956). La carga de la prueba. (1a ed.). Buenos Aires, Argentina: Jurídicas Europa América.

Sainz de Bujanda, F. (1991) Lecciones de Derecho Financiero (9a ed.), Madrid, España: Universidad Complutense Facultad de Derecho Sección de Publicaciones.

Sentis, S. (1979). La prueba, los grandes temas del derecho probatorio (1a ed.), Ediciones Jurídicas Europa América.

Sociedad Nacional de Minería, Petróleo y Energía (2015). XIV Simposium de Tributación Minero-Energética (1a ed.), SNMPE.

Yacolta, D., Bravo, J., Gamba, C., Lara, J., Muñoz, J., Cruzado, V.,...Escalante, A. (2012). Tratado de derecho procesal tributario. (1a ed.). Lima, Perú: Pacifico Editores. 


\section{BIBLIOGRAFÍA}

Aguirre, A. (2010). Fiscalización tributaria. Como afrontarla exitosamente. (1a ed.). Lima, Perú: Gaceta Jurídica.

Cespedes, A., Santos, A., Abruña, A., Strobel, B., Ari, C., Ochoa, C.,...Rhein, V., (2011). La ley del procedimiento administrativo general diez años después. Lima, Perú: Palestra Editores.

Espinoza-Saldaña, E. (2003). Jurisdicción constitucional impartición de justicia y debido proceso. (1a ed.). Lima, Perú: Ara editores.

Gálvez, R. (2005). La fiscalización tributaria. Como asesorar a los contribuyentes ante una fiscalización de la SUNAT. (1a ed.). Lima, Perú: Gaceta Jurídica.

Rodriguez-Bereijo, M. (2012) La documentación de las operaciones vinculadas ¿cuestión de obligación o carga de la prueba para el contribuyente? (segunda parte). Análisis Tributario, XXV (294), 9-15.
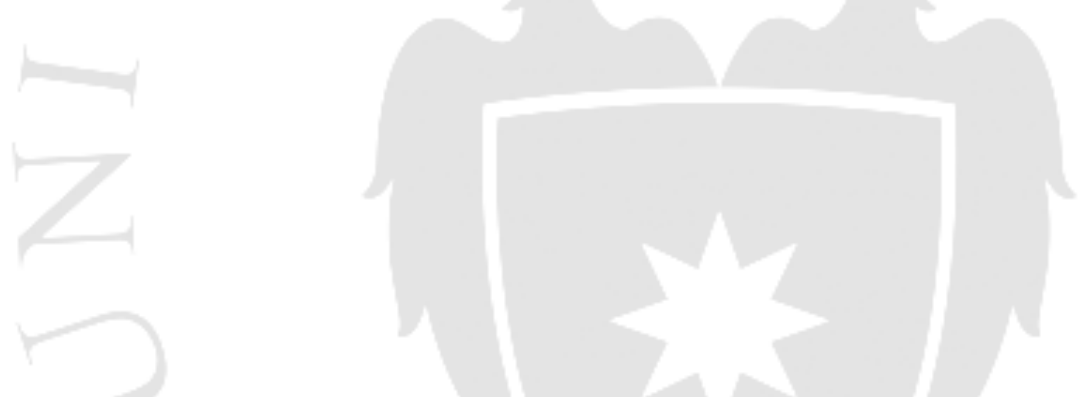